\title{
Ground Water Resources of the Mille Lacs Lake Area, East-Central Minnesota
}

By L.C. Trotta and T.K. Cowdery

U.S. Geological Survey

Water-Resources Investigations Report 97-4116

Prepared in cooperation with the Mille Lacs Band of Chippewa Indians 


\section{U.S. DEPARTMENT OF THE INTERIOR \\ BRUCE BABBITT, Secretary \\ U.S. GEOLOGICAL SURVEY}

Thomas J. Casasdevall, Acting Director

For additional information write to:

District Chief

U.S. Geological Survey 2280 Woodale Drive

Mounds View, MN 55112
Copies of this report can be purchased from:

U.S. Geological Survey

Branch of Information Services

Box 25286

Denver, Colorado 80225-0286 


\section{Contents}

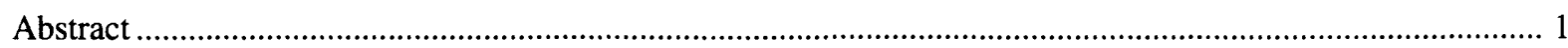

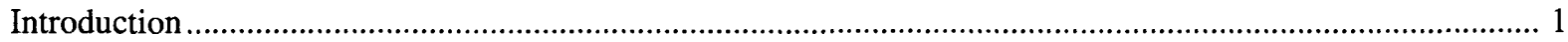

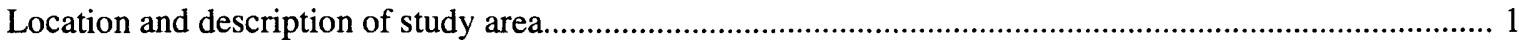

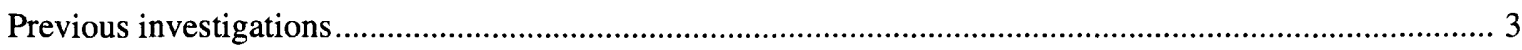

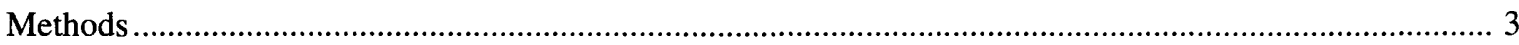

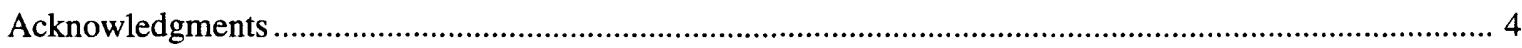

Ground water occurrence, development. and quality............................................................................... 4

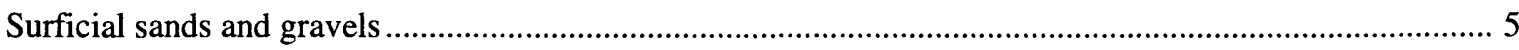

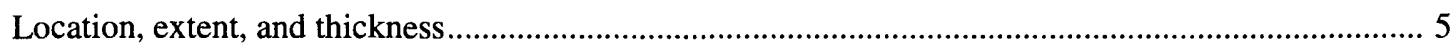

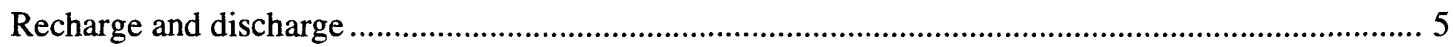

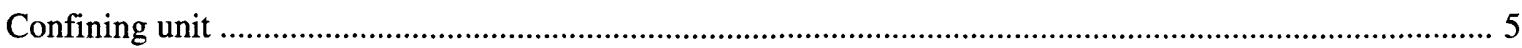

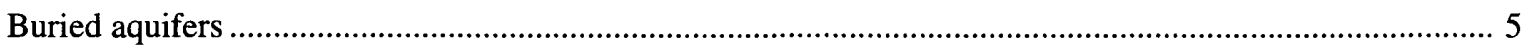

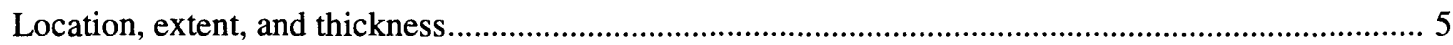

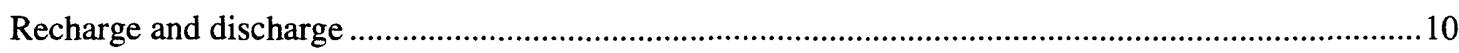

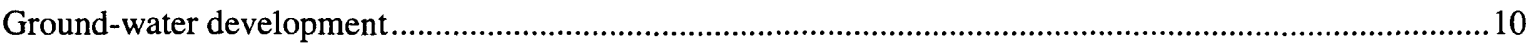

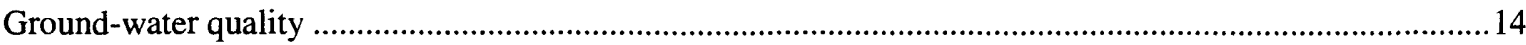

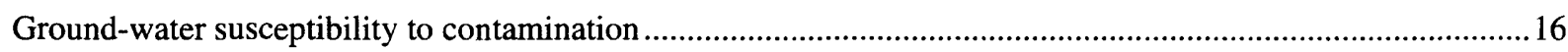

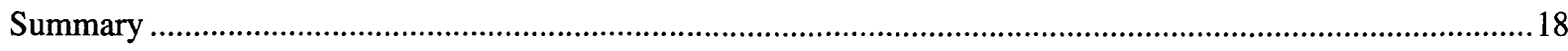

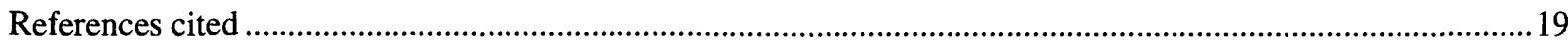

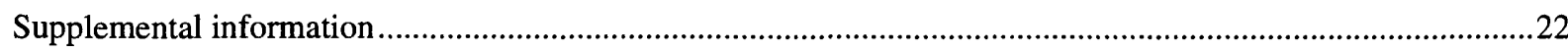

\section{Illustrations}

Figures 1-2. Map showing:

1. Location of Mille Lacs Lake study area, wells, and sampling sites by sample type. .................... 2

2. Surficial sands and gravel thickness in the Mille Lacs Lake study area........................................ 6

Figure 3. Hydrogeologic section A - A' near Lake Onamia. .................................................................. 7

Figures 4-8. Maps showing:

4. Confining-unit thickness in the Mille Lacs Lake study area......................................................... 8

5. Uppermost confined glacial aquifer thickness in the Mille Lacs Lake study area.......................... 9

6. Altitude of the top of the uppermost confined glacial aquifers in the Mille Lacs Lake

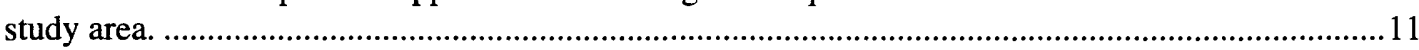

7. Bedrock-surface altitude in the Mille Lacs Lake study area....................................................12

8. Generalized potentiometric-surface altitude and waste disposal sites in the Mille Lacs

Lake study area ......................................................................................................................... 13

Figure 9. Trilinear diagram showing major-ion composition of ground water in the Mille Lacs Lake study area, 1992-93.

\section{Tables}

Table 1. Estimated ground-water use in the Mille Lacs Lake study area, 1992 .............................................14

2. Well yield and specific capacity in the Mille Lacs Lake study area....................................................14

3. Mille Lacs Lake ground-water samples exceeding United States Environmental Protection Agency drinking water standards and health advisories......................................................................16

4. Trace elements and organic compounds analyzed in ground water from three wells in the Mille Lacs Lake study area..

5. Confining unit thickness, well depth, and tritium concentration of ground water from the south side of Mille Lacs Lake, 1991

6. Characteristics of selected wells in the Mille Lacs study area............................................................23 


\section{Tables-continued}

Table 7. Vertical hydraulic conductivity from drill cores collected in the Mille Lacs study area.......................25

8. Major-ion and related data from aquifers in the Mille Lacs study area ...............................................26

9. Nutrient data from aquifers in the Mille Lacs study area ..............................................................28

\section{Conversion factors, vertical datum, and abbreviated water-quality units}

\section{Multiply}

inch (in.)

inches per second (in./s)

inches per year (in.yr)

foot $(\mathrm{ft})$

mile (mi)

foot per day (ft/d)

cubic foot per second $\left(\mathrm{ft}^{3} / \mathrm{s}\right)$

gallon (gal)

gallon per day ( $\mathrm{gal} / \mathrm{d}$ )

gallon per minute ( $\mathrm{gal} / \mathrm{min}$ )

gallon per minute per foot $(\mathrm{gal} / \mathrm{min} / \mathrm{ft})$

million gallons per day $(\mathrm{Mgal} / \mathrm{d})$

square mile $\left(\mathrm{mi}^{2}\right)$

By

To obtain

25.4

2.54

.3048

1.609

.3048

28.32

.003785

.003785

.06309

.00222

.04381

2.590 millimeter

centimeters per second

centimeters per year

meter

kilometer

meters per day

liter per second

cubic meter

cubic meter per day

liter per second

cubic meters per second per foot

cubic meter per second

square kilometer

Chemical concentration are given in metric units. Chemical concentrations in water are given in milligrams per liter $(\mathrm{mg} / \mathrm{L})$ or micrograms per liter $(\mu \mathrm{g} / \mathrm{L})$. Milligrams per liter is a unit expressing the concentration of chemical constituents in solutions as mass (milligrams) of solute per unit volume (liter) of water. One thousand micrograms per liter is equivalent to one milligram per liter. For concentrations less than $7,000 \mathrm{mg} / \mathrm{L}$, the numerical value is the same as for concentrations in parts per million

Sea level In this report "sea level" refers to the National Geodetic Vertical Datum of 1929-a geodetic datum derived from a general adjustment of the first-order level nets of both the United States and Canada, formerly called "Sea Level Datum of 1929".

Use of firm names in this report is for identification purposes only and does not constitute endorsement by the U.S.

Geological Survey 


\title{
GROUND-WATER RESOURCES OF THE MILLE LACS LAKE AREA, EAST- CENTRAL MINNESOTA
}

\section{By Lee C. Trotta and Timothy K. Cowdery}

\begin{abstract}
The Mille Lacs Lake study area is a $960 \mathrm{mi}^{2}$ area containing the ground-water and surface-water drainages to both Mille Lacs Lake and the first 12 miles of the Rum River. Within this study area, available ground water occurs in saturated, overlapping, discontinuous, partially-connected, glacially-deposited (hereinafter, glacial) aquifers and in bedrock aquifers. No extensive glacial aquifer could be delineated. Surficial aquifers generally are less than 30 feet thick, but may exceed 78 feet. Lake Onamia is hydraulically connected with surficial aquifers on its north and south sides. Ground water enters Lake Onamia from an adjacent surficial aquifer with a hydraulic head of 1.56 feet near its eastern shore.

Glacial aquifers buried beneath till form the uppermost confined (hereinafter, buried) aquifers and generally are from 3 to 15 feet thick, but may be as much as 118 feet thick. These buried aquifers generally occur beneath 10 to 60 feet of till and clay, but it may be as thick as 208 feet. Individual aquifers can be partially buried by till and therefore may contain surficial and buried areas. Most buried aquifers are isolated or only partially connected to other aquifers. Recharge water moves horizontally and vertically through other aquifers and through confining units to reach these buried aquifers. Discharge from these aquifers is through well withdrawals, flow to surface-water bodies, and leakage to other aquifers. Buried aquifers may yield as much as $\mathbf{5 0 0}$ gallons per minute in some locations. In most areas, the specific capacity of these aquifers is less than 1 gallon per minute per foot but may reach 41.6 gallons per minute per foot.

Ground water from all aquifers is of the calcium magnesium bicarbonate type. Iron, manganese, and sodium in this ground water frequently exceeded U.S. Environmental Protection Agency drinking water standards and health advisories. The sodium health advisory was exceeded in 15 percent of samples.
\end{abstract}

\section{Introduction}

Ground water is an important resource in the Mille Lacs Lake area (fig. 1). Ground-water resource managers from the Mille Lacs Band of Chippewa Indians are interested in the development potential of this ground water and are concerned about protecting it from potential contamination as a result of human activities. Managers also are interested in whether water-level fluctuations in Lake Onamia (fig. 1), used for wild rice production, are related to the groundwater flow in an adjacent surficial aquifer.

In cooperation with the Mille Lacs Band of Chippewa Indians, the U.S. Geological Survey investigated the ground-water resources of the Mille Lacs Indian Reservation and the surrounding area from 1991 through 1993. The Band requested this study in response to a 1978 Federal mandate that required the Bureau of Indian Affairs to review Indian water-rights claims on reservations throughout the United States. Ground water in the Mille Lacs Lake area occurs in saturated, overlapping, discontinuous, partially-connected, glacially-deposited (hereinafter, glacial) sands and gravels and bedrock aquifers. The glacial sediments in this area are of several origins and textures and are underlain by Precambrian crystalline and sedimentary bedrock. The coarse-grained deposits within the glacial sediments form aquifers. The uppermost confined (hereinafter, buried) aquifers are coarse-grained deposits nearest the land surface that are overlain by relatively impermeable till or lake clay. Of these, one buried aquifer is the major source of water for the Mille Lacs Indian Reservation. Other deeper glacial and bedrock aquifers also exist throughout the study area, but are beyond the scope of this report.

This purposes of this report are to: (1) describe groundwater occurrence and quality in the surficial and uppermost buried aquifers of the Mille Lacs Lake area, (2) define the interaction between ground water and Lake Onamia, and (3) describe susceptibility to contamination of the ground water in these aquifers.

\section{Location and Description of Study Area}

The $960-\mathrm{mi}^{2}$ study area includes the ground- and surface-water drainages of both Mille Lacs Lake and the first 12 miles of the Rum River (fig. 1). This area includes portions of Mille Lacs, Aitkin, Crow Wing, Kanabec, and 


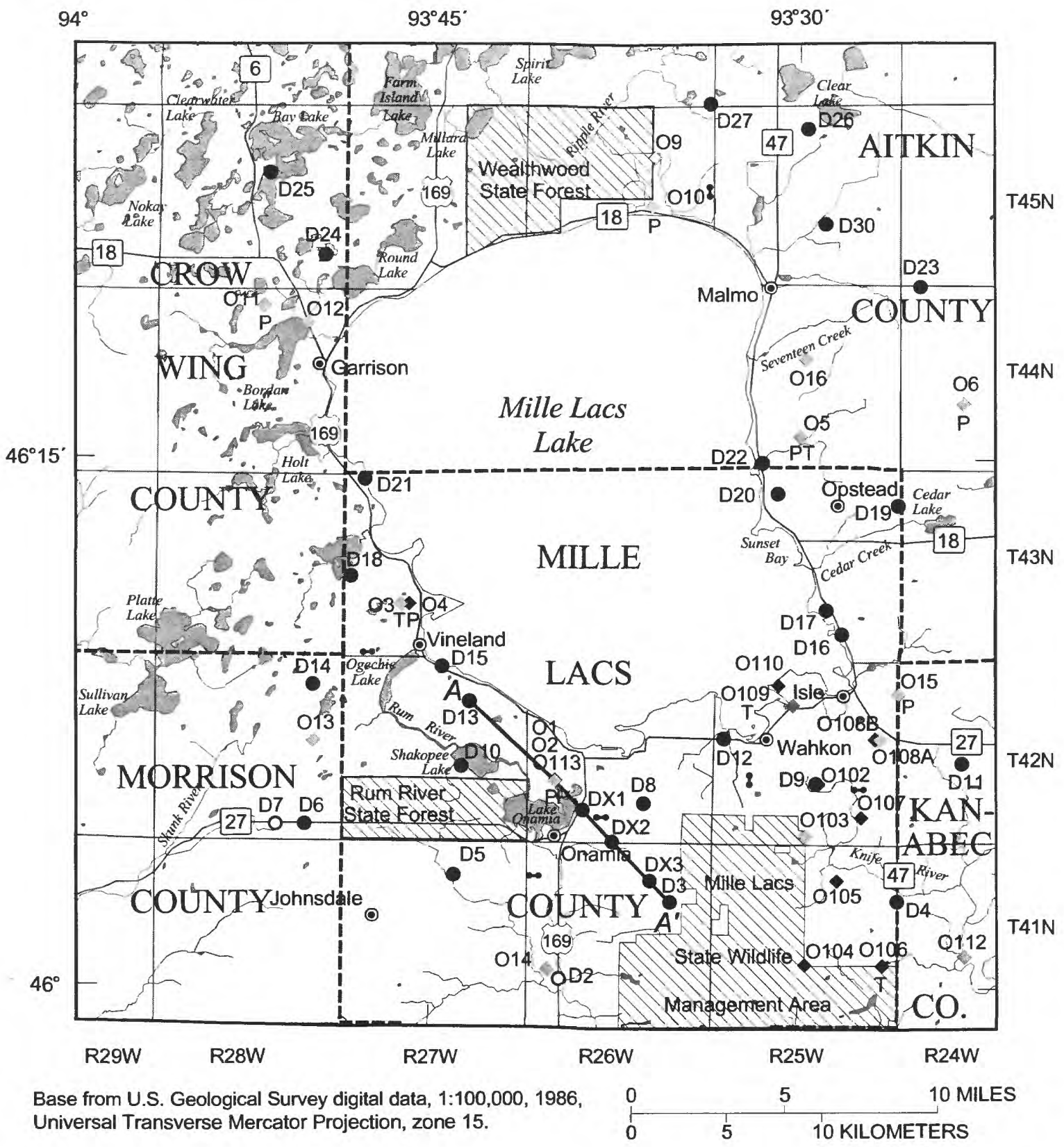

\section{EXPLANATION}

\section{Mille Lacs Indian Reservation
$A-A^{\prime}$ Hydrogeologic cross section (shown in figure 3)

--- County boundary

- Seismic transect
0112 Observation Wells (location and well number)

Major ion, nutrient, and organochlorine analysis

- Major ion and nutrient analysis

- No chemical analysis

T T=Grain-size and composition analysis, $\mathrm{P}=$ Hydraulic-conductivity test

Domestic Wells (location and well number)

O Nutrient, trace metal, and organic pollutant analysis Major ion and nutrient analysis

No chemical analysis

Figure 1. Location of Mille Lacs Lake study area, wells, and sampling sites by sample type 
Morrison Counties and contains the Mille Lacs Indian Reservation. The western part of the study area is famous for the picturesque lakes and hills of the Mille Lacs moraine (Schwartz and Thiel, 1963, p. 259). Except for this moraine, the study area is flat, containing many large wetlands. Average annual precipitation is 28.2 inches (Kanivetsky, 1979, p. 9), most of which occurs as rain between May and September. Average annual potential evapotranspiration is about 38 inches (Baker and others, 1979, p. 9) and average annual runoff is about 6.2 inches (Kanivetsky, 1979, p. 9).

The land cover is characterized by mixed forest, agricultural lands, and wetlands. Agricultural lands are used primarily for pasture, and hay and corn production.

Wetlands are present throughout the area and include large peat bogs in the Rum River State Forest, Mille Lacs State Wildlife Management Area, and Wealthwood State Forest (Breining, 1992, p. 46). Commercial areas are concentrated near Mille Lacs Lake. These areas include light industry, transportation, general commerce, and are dominated by the resort industry.

\section{Previous Investigations}

Warren Upham (Winchell, 1888) first described the glacial geology of the Mille Lacs Lake area. This work was re-evaluated by Leverett (1932) who recognized multiple glacial advances in the area. Schneider (1956) and Wright (1956) realized that the glacial landforms in central Minnesota were formed by multiple advances of several ice lobes. Wright (1964) and Wright and Ruhe (1965) described the complex glacial history of central Minnesota as phases of different ice lobes on the basis of geomorphology and stratigraphy. Hobbs and Goebel (1982) compiled a comprehensive map of the Quaternary deposits of the study area (and throughout Minnesota). Mooers (1988) developed a glacial-process facies model to explain the construction of the landforms of the St. Croix moraine and the recessional ice margins of the Rainy and Superior lobes of the Laurentide ice sheet in central Minnesota. These lobes produced the landforms (including the Mille Lacs moraine) in the study area. Southwick and others (1988) constructed a bedrock geology map of central and eastern Minnesota with a discussion of the genesis of these rocks.

Ground-water resources of the area were described in the context of the bedrock and glacial geology by Thiel (1947), Ericson and others (1974), and Myette (1986). Walsh (1992) included Mille Lacs County in his study of tritium in ground water and well vulnerability to contamination. The surface-water quality of the Mille Lacs Lake watershed has been investigated (Adams, Grover and Associates, Inc., written commun., 1976), but publications specific to the area are few. The lake sediments of Mille Lacs Lake are described by Swain (1992).

\section{Methods}

Buried aquifers are defined, in this report, as the uppermost, glacially-deposited sand and gravel at least three feet thick, buried by at least 10 feet of till or lake clay. Hereinafter these confining deposits will be referred to as till because most of the confining deposits are till. Twenty-five observation wells (2-inch or 4-inch diameter) were drilled for this study (fig. 1) using mud-rotary or power-auger drilling methods. These wells were completed at depths from 7 to 160 feet (see Supplemental Information section, table 6). Stratigraphic, water-level, and water-quality data collected from 1991 through 1993 for this study from 25 observation wells, 29 domestic wells and 5 seismicrefraction transects (fig. 1) were combined with historical data from 688 wells and test holes as the basis of this report.

Hydraulic heads were measured with a minipiezometer to determine ground-water flow into or out of Lake Onamia. Water levels in wells measured during this study were combined with historical data. The potentiometric map in this report was constructed by plotting the altitude of water levels in all surficial, buried and deeper glacial aquifers, and drawing lines of equal waterlevel altitude. A potentiometric map constructed in this way assumes that: 1) water levels have not changed significantly in an area over time; 2) surficial, buried, and deeper glacial aquifers are hydraulically connected; and 3) localized ground-water withdrawals do not affect regional water levels.

Cuttings (43 samples) were collected during drilling of 4 wells for this study. These samples represent the glacial materials. These samples were analyzed at the University of North Dakota for grain size and composition (Folk, 1974) to estimate the hydraulic conductivity of the materials.

Hydraulic conductivity was determined for 13 core samples collected at 8 sites in a triaxial-like chamber by the flexible wall method (Donald Voigt, Twin City Testing Corporation, 1993, written commun.) (fig. 1; Supplemental Information section, table 7) The hydraulic conductivity measured in these tests is only approximate because core samples were disaggregated and repacked into the measuring chamber, destroying the original fabric of the sample.

Water-quality samples were collected from 17 observation wells, and 26 domestic wells during September 1992 and March 1993. These wells were screened in surficial glacial or buried glacial, or bedrock aquifers, 7 to 216 feet below land surface (fig. 1; Supplemental Information section, table 6). All ground-water samples were analyzed for major ions (Supplemental Information section, table 8) and nutrients (Supplemental Information section, table 9) except for two domestic well samples (D2 and D7) that were analyzed for nutrients only. D2 and D7 were also analyzed for polycyclic aromatic hydrocarbons (PAH's), commonly found pesticides and their metabolites, 
trace metals, and volatile organic compounds (VOC's). One observation well sample (O9) was also analyzed for organochlorine chemicals (pesticides and industrial compounds) in addition to major ions and nutrients. These water-quality data were used to characterize the groundwater quality from the surficial and buried aquifers throughout the study area. Stark and others (1991, p. 54) summarize the sample-collection techniques used. A peristaltic or submersible pump was used to purge and sample the observation wells, and installed pumps were used to sample domestic wells. All samples were analyzed at the U.S. Geological Survey National Water Quality Laboratory in Arvada, Colorado.

Quality-control methods used to test for possible errors in the water-quality data due to sampling, shipping, and analysis included: 1) blind standard reference samples analyzed by the U.S. Geological Survey National Water Quality Laboratory (Long and Farrar, 1993); and 2) collection of two replicate samples to assess sampling variability. Concentrations of major ion and nutrient concentrations in each set of replicate samples agreed within 7 percent. The cation-anion balances for both replicate sets agreed within 3 percent. Results from the quality-control samples indicate that sampling and analytical techniques produced accurate results for major ions and nutrients.

Water-use data were obtained from the Minnesota Water-Use Data System at the Minnesota Department of Natural Resources. These water-use data were supplemented with a field survey discussed in the Supplemental Information section.

\section{Acknowledgments}

We acknowledge the cooperation of the staff of the Mille Lacs Indian Reservation Environmental Laboratory for their help and advice. We also are grateful to well owners, well drillers, and State and local agencies for data used in this report. Special thanks is given to Eric Woods for his volunteer help in data compilation.

\section{Ground-water occurrence, development, and quality}

Ground water in the Mille Lacs Lake area is obtained from surficial, buried, and bedrock aquifers. The Mille Lacs Lake area is underlain by Precambrian crystalline bedrock. Bedrock is exposed at the land surface along some streams south of Mille Lacs Lake and at isolated locations east of Opstead (Southwick and others, 1988). Joints and fractures in the crystalline bedrock may yield small amounts of ground water. Bedrock aquifers are not discussed further in this report.

Saturated, coarse-grained glacial sediments comprise glacial aquifers and are found across the study area. These aquifers are both at the surface and buried within till and lake clay. An individual buried aquifer is surrounded by till, or may be in hydraulic connection, either vertically or horizontally, with other aquifers. In some areas, an aquifer may be partially buried by till and, therefore, have a surficial portion and a buried portion. No individual aquifers could be delineated because the deposits are complex and stratigraphic data are limited. However, by considering the glacial genesis of these sediments, a sense of the shape, size and positional interrelations of these aquifers can be gained.

Lobes of continental ice sheets flowed across the study area and deposited sediments many times during the last 2 million years. The sequence of this glaciation is documented by Wright (1956 and 1972) and Mooers (1988). Most of the near-surface sediments were deposited by glaciers of Wisconsinan age $(60,000-12,000$ years ago). Glaciers deposit two basic types of sediments: coarsegrained and fine-grained. Coarse-grained sediments are deposited as a glacier melts. Flowing glacial meltwater sorts rock material contained in the glacier, carrying the fine materials away and depositing the coarser sands and gravels within the glacier or near its margins. The shape of these deposits can vary between planar, sheet-like bodies and sinuous or lens-shaped bodies. The sheet-like deposits are usually formed in front of the melting glacier while the lensshaped deposits are usually formed within or on top of the glacier. The coarse-grained glacial deposits that result from these processes become aquifers if they are saturated.

Fine-grained sediments are deposited at the base of an advancing glacier or on top of a receding glacier. When glacial ice melts, rock material contained within the glacier accumulates and is deposited as unsorted till. Because the grain size of till ranges from clay to boulders, the finer grains fill voids between larger grains making the deposit relatively impermeable to water flow. Impermeable, well-sorted clays can also form in glacial environments where clay-laden meltwaters enter ponds or lakes, either within, upon, or beyond the glacial margin. These fine-grained sediments form confining units, retarding ground-water flow to or between aquifers.

Coarse-grained and fined-grained materials are also deposited along the margins of receding glaciers. These deposits, called glacial moraines, are typically hummocky, topographically high, hilly areas containing lakes, ponds, and wetlands. Beyond the moraine, sediment-laden streams from the glacier may form outwash plains. The western and northern parts of the study area contain part of the Mille Lacs moraine which marks the edge of the Superior lobe of the Laurentide ice sheet 20,000 to 15,000 years ago (Wright, 1972). This moraine (marked by the area of many smaller lakes, fig. 1), which rises 130 feet above the lake surface south of Garrison, blocked surface-water drainage to the southwest, forming Mille Lacs Lake. West of the moraine, surficial sands form a narrow outwash plain from Platte 
Lake in the south to Nokay Lake, northwest of Garrison (Mooers, 1988) (fig. 1).

\section{Surficial sands and gravel}

\section{Location, extent, and thickness}

The surficial sands and gravels, which are aquifers if saturated, are small, isolated, widespread, may thin or discontinue between wells, and may be separated by thin tills. Surficial sands and gravels may have originated as beaches or as outwash deposits, as they are present around lakes or along the Rum River (fig. 2). Areas where surficial sands and gravels are present also contain private domestic wells where well drillers reported no surficial sand and gravel in well logs (black dots, fig. 2).

The distribution of surficial sands and gravels in figure 2 likely are skewed by domestic well location because most homes in the area are located near lakes and rivers. The largest areas of surficial sands and gravels are located near Mille Lacs Lake, north of Lake Onamia and south of Lake Onamia along the Rum River, near Isle, Vineland, Garrison, and Bay Lake. These sands and gravels are less than 30 feet thick. The maximum reported sands and gravels thickness was greater than $78 \mathrm{ft}$.

The surficial aquifer surrounding Lake Onamia is in hydraulic connection with the lake, based on a minipiezometer survey of the lake bottom. This aquifer extends north of Lake Onamia, probably to Mille Lacs Lake, and to the south along the Rum River. The aquifer is surficial, but is sometimes overlain by silty deposits that may bury it locally. The aquifer is less than 10 feet thick north of Lake Onamia, but is thicker and more widespread south of the lake.

\section{Recharge and discharge}

Recharge to surficial aquifers is by infiltration of rain and snowmelt or by seepage from lakes, wetlands, and streams. Water from surficial aquifers discharges to these same surface-water bodies, to other aquifers, to the atmosphere through evapotranspiration, and to wells. Hydraulic head in the bottom sediments of Lake Onamia was measured with a minipiezometer along its southern and eastern shores. During winter 1993, hydraulic head in the aquifer along the southeastern shore was 1.56 feet higher than the lake level. The head difference indicates that ground water discharges to the lake from this aquifer in this area. This aquifer also discharges to the Rum River in the Lake Onamia area. Flow in the Rum River increased 11 $\mathrm{ft}^{3} / \mathrm{sec}$ between the Mille Lacs Lake outlet and the city of Onamia during base flow in 1970. This flow also may have included discharge from buried aquifers.

Hydrogeologic section $A$ to $A^{\prime}$ (fig. 3) shows the relation between the lake and underlying and adjacent aquifers, as well as the interconnection with other surficial and buried aquifers along the section. The water levels in the lakes, wetlands, and wells decrease from the Mille Lacs moraine (high hilly area in the section) and from well D3 (southeast end of the section) toward Lake Onamia. This indicates that the lakes, wetlands, and surficial aquifers supply water to Lake Onamia. The domestic wells completed in the surficial aquifer around Lake Onamia may yield as much as $20 \mathrm{gal} / \mathrm{min}$.

\section{Confining unit}

The confining unit, for this report, is defined as all finegrained sediments between the land surface, or the base of the surficial aquifers, and the top of the uppermost buried aquifers. The confining unit is composed of till, but may also contain thin layers of clay and lenses of gravel, sand or silt (less than 3 feet thick). The confining unit must be at least 10 feet thick (fig. 4) to protect underlying aquifers from contamination from land uses according to the Geologic Sensitivity Project Workgroup (1991, p. 66-67). Aquifers overlain by less than $10 \mathrm{ft}$ of till are considered surficial aquifers in this report. Sand or silt lenses within the till may be as much as 3 feet thick. In some areas, till extends from land surface, or the bottom of a surficial aquifer, to the bedrock surface, and no buried aquifer is present. The depth to the top of the buried aquifer may be greater than the thickness of the confining unit (fig. 4) because of sand and gravel lenses present within the confining unit or by the presence of surficial sand and gravel.

Tills at land surface in central Minnesota range from $60 \%$ sand and gravel, $30 \%$ silt and $10 \%$ clay, to $71 \%$ sand and gravel, $18 \%$ silt, $11 \%$ clay (Mooers, 1988). Tills from test holes drilled for this project have an average of $16 \%$ gravel, $43 \%$ sand, $32 \%$ silt, and $9 \%$ clay. Some of the clay in tills is from the test holes drilled for this project may be drilling mud. The hydraulic conductivity measured in triaxial chambers filled with repacked core material ranged from $9.92 \times 10^{-4} \mathrm{ft} / \mathrm{d}$ in well 011 to $1.67 \times 10^{-1} \mathrm{ft} / \mathrm{d}$ in well O1 compares well with the range of hydraulic conductivity published for till $\left(1 \times 10^{-3} \mathrm{ft} / \mathrm{d}-1 \times 10^{-1} \mathrm{ft} / \mathrm{d}\right.$ (Fetter, 1988)).

The confining unit is greater than 40 feet thick at $61 \%$ of wells shown in figure 4. Buried aquifers located in areas overlain by confining units less than $40 \mathrm{ft}$ thick are located southwest of Vineland, from Onamia to Johnsondale, south and west of Wahkon, east of Isle, north and east of Opstead, and northwest of Garrison.

\section{Buried aquifers}

\section{Location, extent, and thickness}

Buried aquifers are composed of sand and gravel, overlain by a confining unit, and are discontinuous (fig. 5). Extensive buried aquifers are not present. Buried aquifers generally are from 3 to 15 feet thick, but may be as thick as 


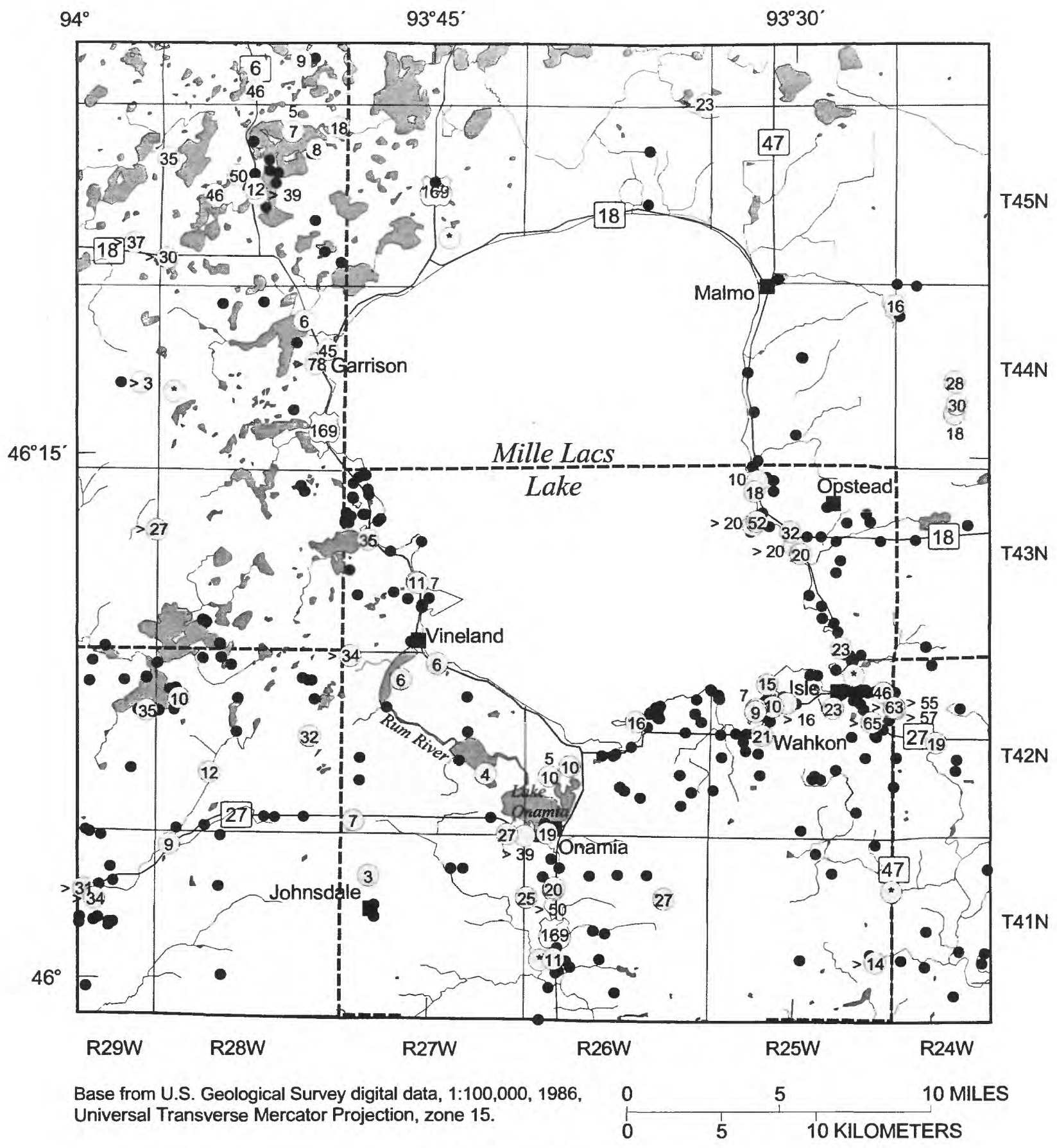

\section{EXPLANATION}

Mille Lacs Indian

Reservation

--- County boundary
34 Well log reporting surficial sand and gravel Total wells: 78 ; thickness range: $3 \rightarrow 78$ feet

Number is sand and gravel thickness; $>$, greater than; ${ }^{*}$, thickness unknown

- Well log reporting no surficial sand and gravel Total wells: 300

Figure 2. Surficial sand and gravel thickness in the Mille Lacs Lake study area. 

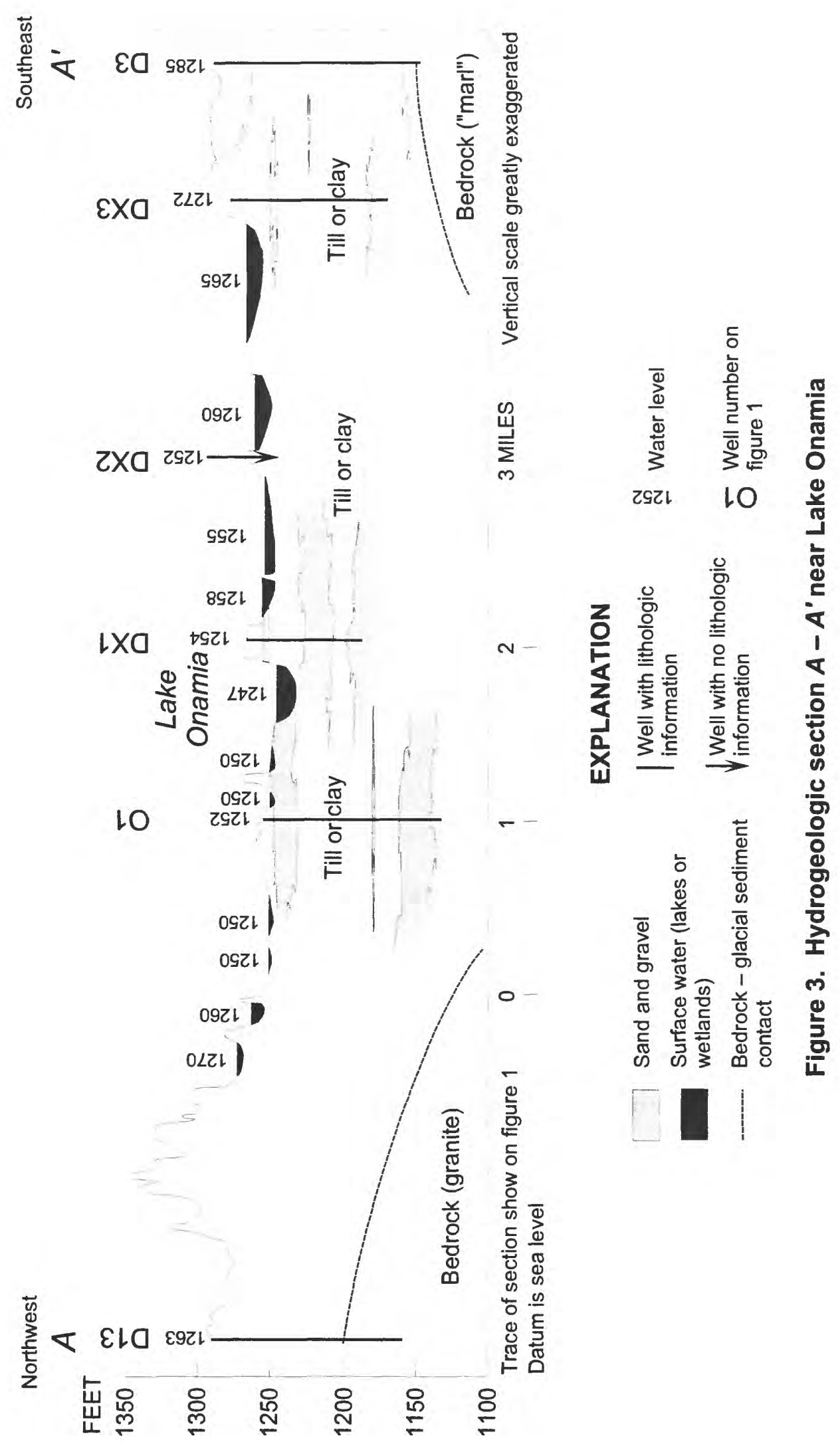


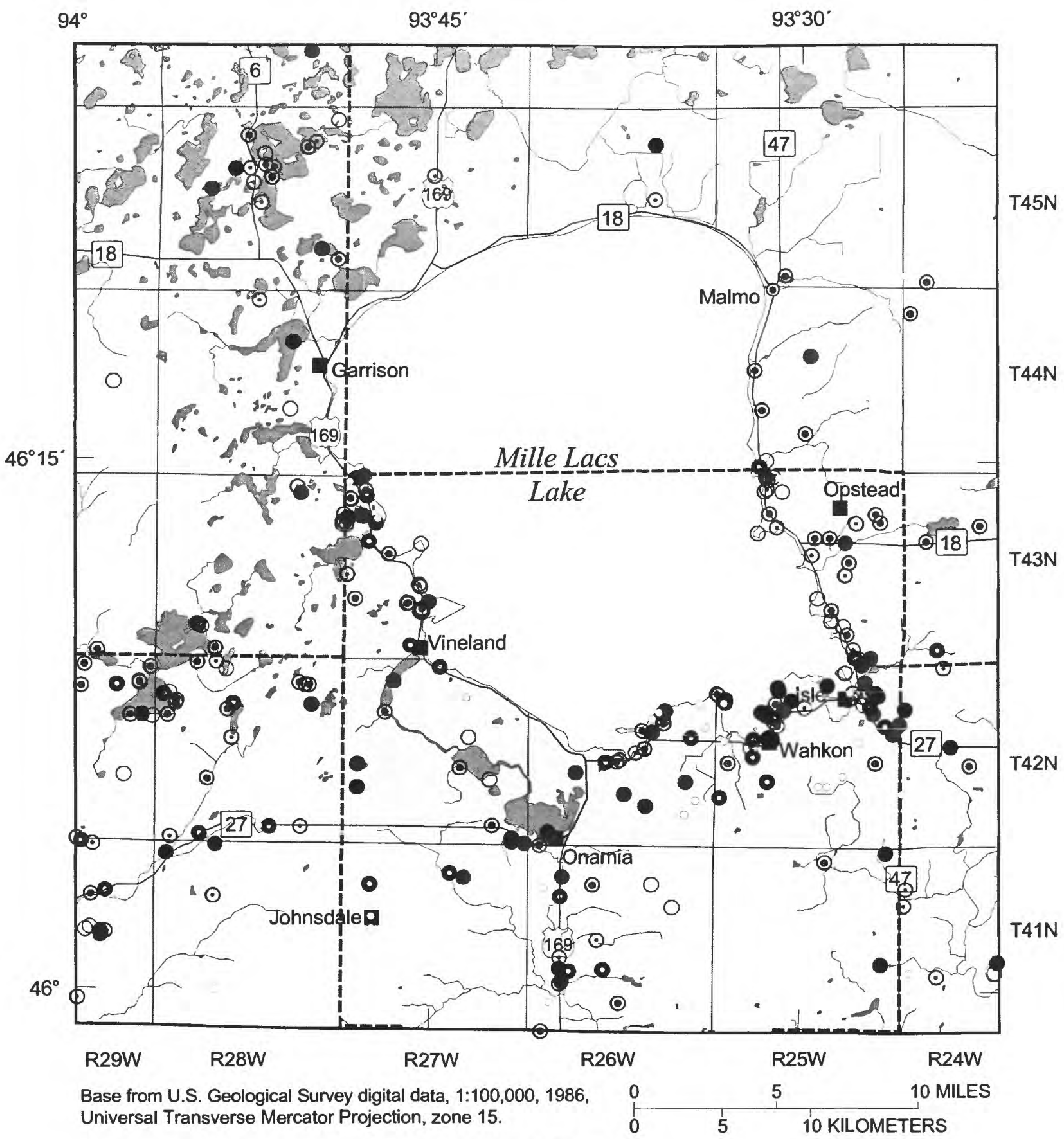

\section{EXPLANATION}

$\square$ Mille Lacs Indian Reservation

--- County boundary

Confining-unit thickness statistics

Total wells: 258

Std. Dev.: 29 feet

Range: $\quad 10-208$ feet Median: 47 feet

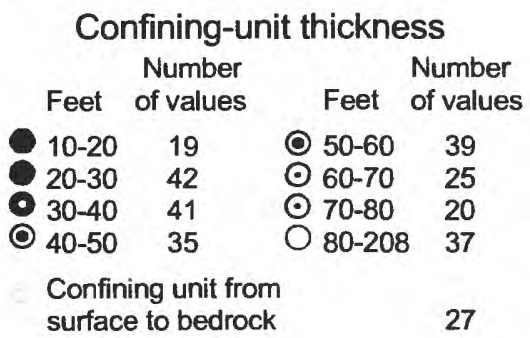

Figure 4. Confining-unit thickness in the Mille Lacs Lake study area. 


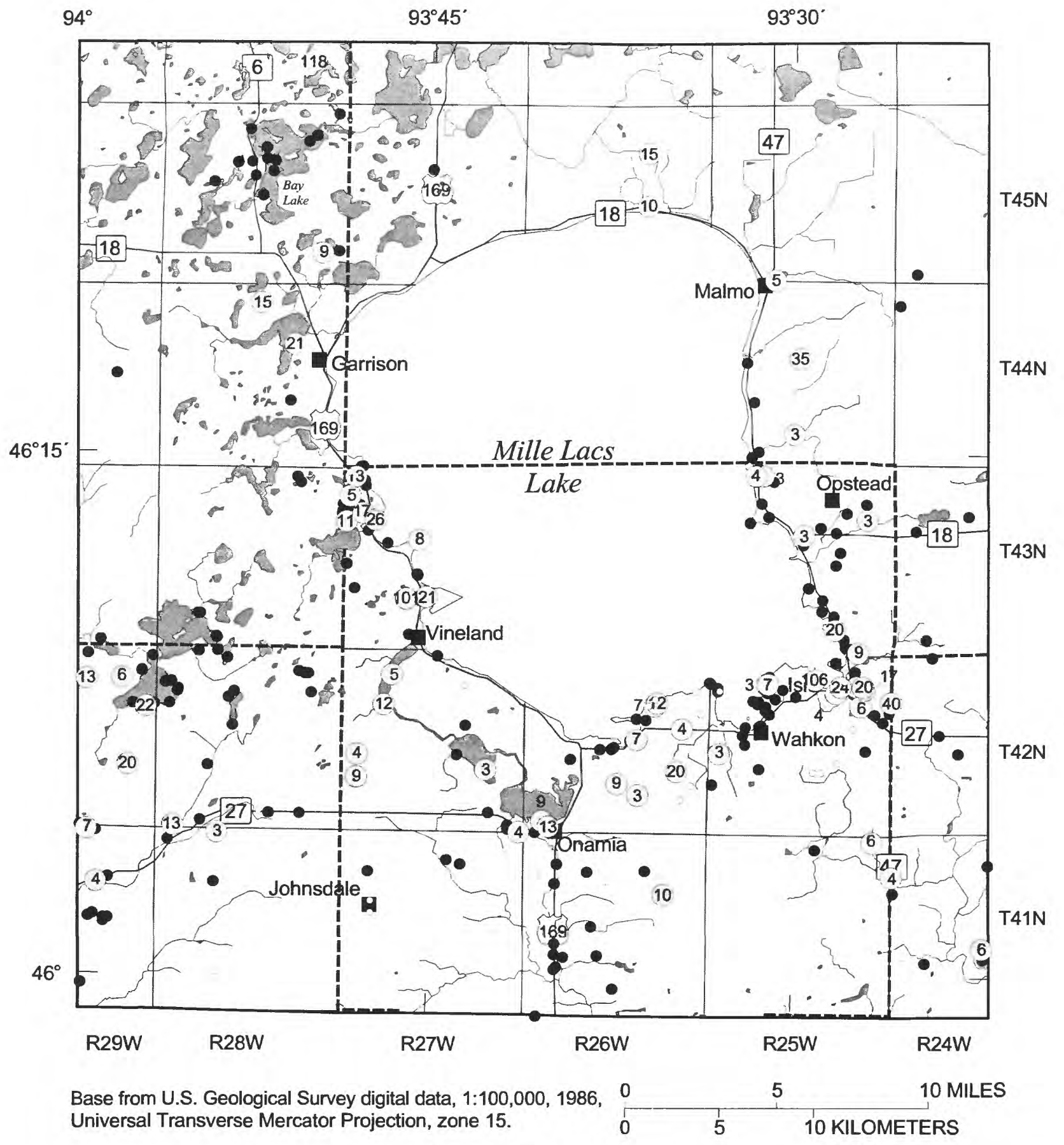

\section{EXPLANATION}

Mille Lacs Indian Reservation

\section{-.-- County boundary}

Aquifer thickness statistics Total wells: $61 \quad$ Std. Dev.: 19 feet Range: $\quad 3-118$ feet Median: 9 feet Mean: 14 feet
34 Wells log reporting an aquifer thickness Number is aquifer thickness

- Well log reporting aquifer, but thickness unknown: 193 wells

Well log reporting no aquifer: 27 wells

Figure 5. Uppermost confined glacial aquifer thickness in the Mille Lacs Lake study area. 
118 feet. The location, shape, extent, and interconnection of the buried aquifers is complex. The altitude of the top of the uppermost buried aquifer in $72 \%$ of wells ranges from 1,175 to 1,250 feet (fig. 6). The tops of buried aquifers are at altitudes greater than $1,250 \mathrm{ft}$ in areas near Johnsdale and Opstead where bedrock surface altitude is also high. Buried aquifers also are absent in these areas and near Wahkon where the bedrock is at or near land surface. The thickest buried aquifers are located north of Vineland, near Isle, and near Bay Lake (fig.5).

The bedrock surface (fig. 7) is characterized by knobs and hollows with a relief of nearly 100 feet (Thiel, 1947, p. 176). The buried aquifers pinch out against bedrock where the bedrock is close to land surface (for example, the Johnsdale and Opstead areas, fig. 7). The confining unit also may pinch out and a buried aquifer may have a surficial portion (for example, south of Wahkon, fig. 4).

The thick buried aquifers, located north of Vineland and near Isle (figure 5), correspond to areas of largecapacity municipal wells. If a large-capacity well is being installed, drillers bypass the thinner, shallower aquifers until they encounter an aquifer thick enough to supply the needed water. The bypassed, thinner aquifers may be capable of supplying a household, but may not be reported in the drilling records because these aquifers are insufficient for municipal use. Figure 5 provides only a guide regarding location and thickness of buried aquifers. It is possible to encounter buried aquifers thicker or thinner than shown in this figure or not to encounter one at all because of the variability of glacial sediments.

\section{Recharge and discharge}

Recharge to a buried aquifer is by leakage through the confining unit, or by infiltration of precipitation where part of the aquifer is at or near land surface. An overlying confining unit slows recharge to the buried aquifers. Fractures in the confining unit may increase recharge to the buried aquifer. Recharge rates to aquifers can be estimated from continuous water-level measurements in observation wells using methods described by Rasmussen and Andreason (1959) and Stark and others (1991, p. 45). Annual recharge was computed for 1992-93 using a hydrograph from observation well O6, completed in a buried aquifer northeast of Opstead. Areal recharge rate was estimated to be $6.86 \mathrm{in} . / \mathrm{yr}$, assuming a specific yield of 0.27 (Myette, 1986, p. 19). Kanivetsky (1979, p. 9) estimated recharge rate of 5.49 in./yr for the Rum River Basin. Discharge from the buried aquifers is: 1 ) by leakage to wetlands, lakes, and streams, 2) by flow to other aquifers, and 3 ) by withdrawals to municipal and domestic wells.

The general direction of ground-water flow (fig. 8) is toward Mille Lacs Lake and the Rum River, which are regional discharge areas. Locally, shallower ground water may flow toward and discharge into small lakes, ponds, and wetlands. Ground water recharged outside the Mille Lacs Lake surface-water basin may discharge to Mille Lacs Lake. For example, ground water mounded north of Bay Lake (area greater than $1,275 \mathrm{ft}$ in fig. 8 , which is outside the Mille Lacs Lake surface-water basin) may flow south and east, toward Round Lake and Mille Lacs Lake, thereby entering the Mille Lacs Lake surface water basin. The opposite may also occur in some areas like those west of Garrison. The ground-water divide for the study area is shown in figure 8. This divide is well defined except in the area southeast of Isle, northwest of Garrison, and in the area north of the central part of Mille Lacs Lake. When ground-water levels in these areas are less than the Mille Lacs Lake level, leakage through clayey lake bottom sediments to glacial and bedrock aquifers will occur. Ground-water flow is toward the Ripple River north of the divide, the Snake River east of the divide, the Knife River southeast of the divide, and the Platte and Skunk Rivers southwest of the divide (all of these rivers except the Snake and Platte, are shown on fig.1). The source of all of these rivers is the Mille Lacs Lake surfacewater divide.

\section{Ground-water development}

Most ground water is withdrawn from buried aquifers. Surficial aquifers are unprotected and thinner, providing less reliable sources of ground water. Wells completed in surficial aquifers generally yield less than $20 \mathrm{gal} / \mathrm{min}$, but may yield more than $100 \mathrm{gal} / \mathrm{min}$ (Myette, 1986).

Substantial ground-water use began in the early 1900's when the Minnesota State Board of Health recommended use of ground water for public-water supply to avoid epidemics of typhoid fever (Woodward, 1985, p. 15-16). By 1968, Onamia and Isle were withdrawing 113 million gallons per year, but withdrawals decreased to 55 million gallons per year when the creamery in Isle closed that year (Brian Rongitsch, Minnesota Department of Natural Resources, 1968, written commun.).

Total ground-water use has not increased much in the area since the 1960's, though the details of the use have changed. Young $(1987$, p. 15) reported one ground water irrigation system in northern Mille Lacs County in 1985. The withdrawal rate has remained steady at $0.13 \mathrm{Mgal} / \mathrm{d}$ since then. During 1985-90, ground-water withdrawals for livestock decreased from $9.5 \%$ to $0.38 \mathrm{Mgal} / \mathrm{d}$. Groundwater withdrawals for public supply increased by $53 \%$ although population served decreased $10 \%$ during the same five-year period. Domestic self supply decreased $14 \%$ during 1985-90. A recent increase in commercial activities on the Mille Lacs Indian Reservation beginning in the early 1990's has increased demand for ground-water. Table 1 shows the major ground-water use for 1992. Details of how these estimates were made are in the Supplemental Information section. Domestic self supply of water is the greatest use of ground water, $60 \%$ of the 708 million gallons of ground water withdrawn that year. 


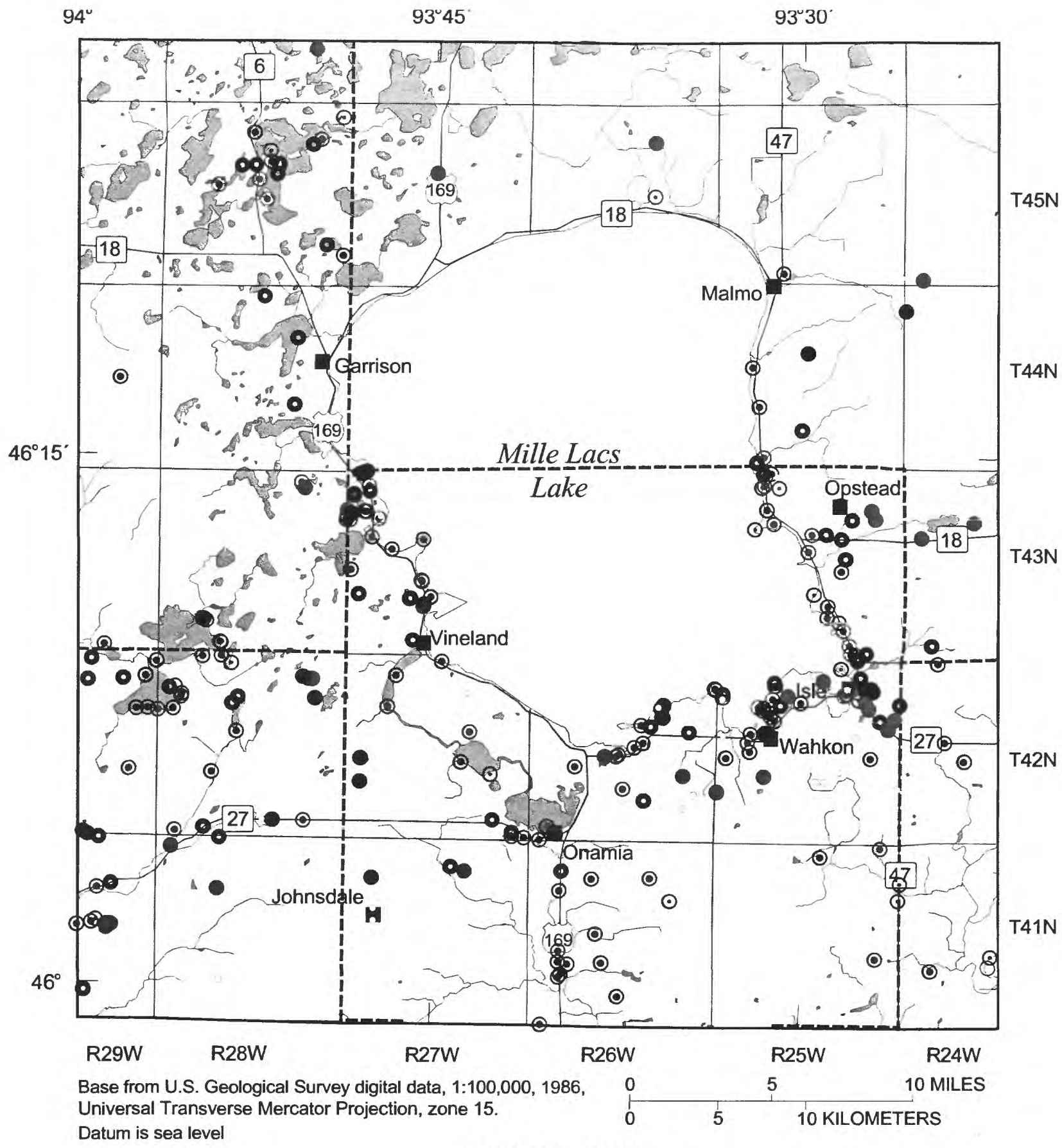

\section{EXPLANATION}

Mille Lacs Indian Reservation

--- County boundary

Buried glacial aquifer altitude statistics

Total wells: $258 \quad$ Std. Dev.: 37 feet

Range: $\quad$ 1003-1311 feet Median: 1220 feet

Mean: 1216 feet

\begin{tabular}{|c|c|c|c|}
\hline \multicolumn{4}{|c|}{ Buried aquifer thickness } \\
\hline $\begin{array}{c}\text { Feet } \\
1275-1311 \\
1250-1275 \\
1225-1250 \\
1200-1225\end{array}$ & $\begin{array}{c}\text { Number } \\
\text { of values } \\
14 \\
27 \\
63 \\
85\end{array}$ & $\begin{array}{c}\text { Feet } \\
\bigcirc 1175-1200 \\
\odot 1150-1175 \\
\odot 1050-1150 \\
\bigcirc 1003-1050\end{array}$ & 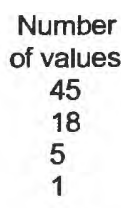 \\
\hline \multicolumn{3}{|c|}{ No buried aquifer } & 27 \\
\hline
\end{tabular}

Figure 6. Altitude of the top of the uppermost confined glacial aquifers in the Mille Lacs Lake study area. 


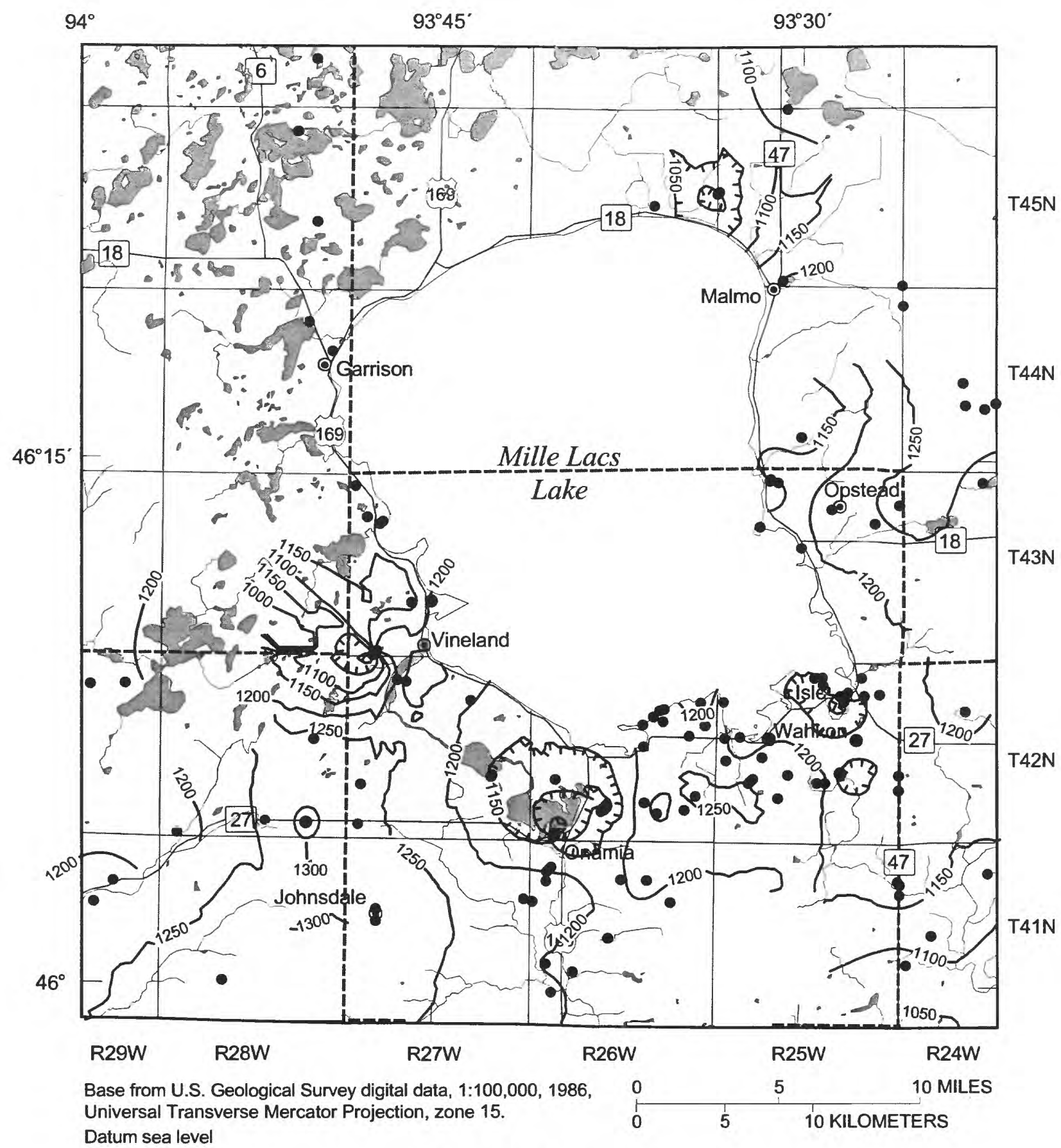

\section{EXPLANATION}

Mille Lacs Indian Reservation

County boundary
- Well log reporting depth to bedrock

- Bedrock-surface contour-shows altitude of top of bedrock.

Interval: 50 feet. Hachures indicate depression. [interpolation method: linear, requiring 6 data within $6 \mathrm{~km}$ for contour]

Figure 7. Bedrock-surface altitude in the Mille Lacs Lake study area. 


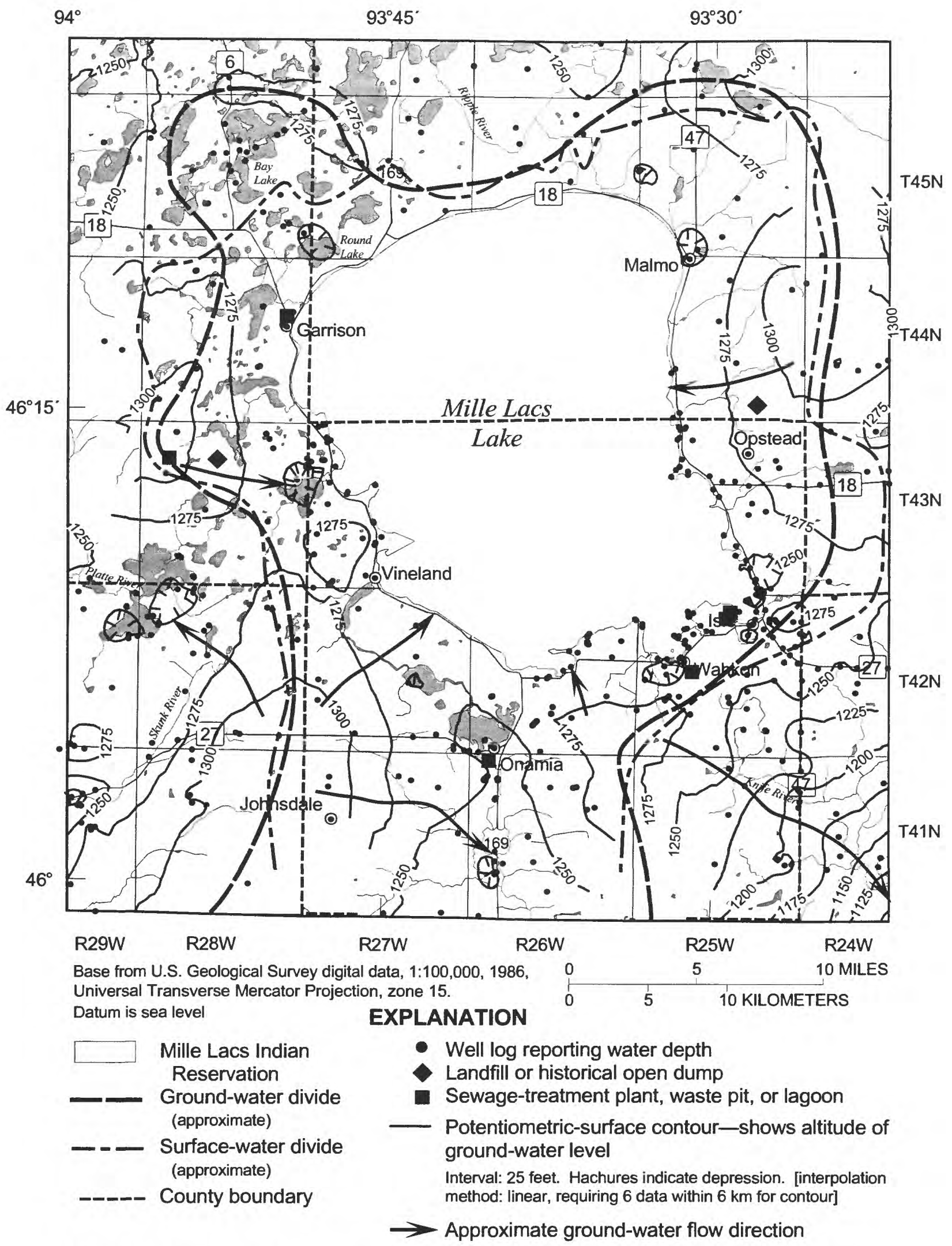

Figure 8. Generalized potentiometric-surface altitude and waste disposal sites in the Mille Lacs Lake study area. 


\begin{tabular}{lll}
\hline $\begin{array}{l}\text { Table 1. Estimated ground-water use in the } \\
\text { Mille Lacs Lake study area, }\end{array}$ & 1992. \\
\hline & $\begin{array}{l}\text { Million } \\
\text { gallons }\end{array}$ & Percent \\
\hline Domestic self supply & 424 & 60 \\
Public supply & 162 & 23 \\
Commercial self supply & 85 & 12 \\
Industrial self supply & 28 & 4 \\
Irrigation & 9 & 1 \\
Total & 708 & 100 \\
\hline
\end{tabular}

The buried aquifers meet current water-supply needs for both residents and businesses. Aquifers vary in water yield partly because of variable saturated thickness.

Reported well yields and specific capacities are shown in table 2. In general, the areas of greatest potential yield coincide with areas of greatest specific capacity. Specific capacities of wells screened in the buried aquifers are less than $1 \mathrm{gal} / \mathrm{min} / \mathrm{ft}$, but are as great as $15 \mathrm{gal} / \mathrm{min} / \mathrm{ft}$ near Isle and the southern shore of Mille Lacs Lake. The buried aquifer near Isle has become partially unsaturated during excessive pumping.

Table 2 - Well yield and specific capacity in the
Mille Lacs Lake study area.
[gal, gallons; /, per; min, minute; ft, foot; <, less than; - , not
reported]

\begin{tabular}{lcc}
\hline \multicolumn{1}{c}{ Well } & $\begin{array}{c}\text { Yield } \\
\text { [gal/min] }\end{array}$ & $\begin{array}{c}\text { Specific } \\
\text { capacity } \\
\text { [gal/min/ft] }\end{array}$ \\
\hline $\begin{array}{l}\text { Mille Lacs Lake Indian Res- } \\
\text { ervation public supply well }\end{array}$ & 500 & 41.6 \\
near Vineland & & \\
$\begin{array}{l}\text { Onamia municipal standby } \\
\text { well }\end{array}$ & 78 & 2.8 \\
$\begin{array}{l}\text { Isle municipal supply well } \\
\text { Garrison area wells }\end{array}$ & 400 & - \\
\hline
\end{tabular}

\section{Ground-water quality}

Water from surficial, buried and bedrock aquifers is of the calcium magnesium bicarbonate type. Calcium, magnesium, and bicarbonate are derived primarily from soil and rock weathering (Hem, 1985). Major ions and nutrients in ground water were determined by analysis of 6 samples from surficial aquifers, 28 samples from buried aquifers, 5 samples from bedrock aquifers and 4 samples from unknown aquifers that were assumed to be buried aquifers. The results of the individual chemical analyses are listed in the Supplemental Information section, tables 8 and 9. Hardness of water from the buried aquifers (26 samples) ranged from 66 to 750 milligrams per liter $(\mathrm{mg} / \mathrm{L})$ of calcium carbonate $\left(\mathrm{CaCO}_{3}\right)$ with a median hardness of 210 $\mathrm{mg} / \mathrm{L} \mathrm{CaCO}_{3}$. Hardness of water from the surficial aquifers (6 samples) ranged from 70 to $290 \mathrm{mg} / \mathrm{L} \mathrm{CaCO}{ }_{3}$ with a median hardness of $180 \mathrm{mg} / \mathrm{L} \mathrm{CaCO}_{3}$. Hardness of water from 5 bedrock aquifers ranged from 240 to $620 \mathrm{mg} / \mathrm{L}$ $\mathrm{CaCO}_{3}$ with a median hardness of $310 \mathrm{mg} / \mathrm{L} \mathrm{CaCO}$.

The predominant ionic composition of water from all aquifers is shown in figure 9. Each data point in the lower triangles was extended to the upper parallelogram to indicate general water type (Freeze and Cherry, 1979, p. 252). The clustering of data in figure 9 indicates the chemical similarity of water from all types of aquifers and wells sampled. Of the 24 major ion, nutrient, and trace metal constituents analyzed in samples from this study, the U.S. Environmental Protection Agency has established drinking water standards or health advisories for 15 of them (U.S. Environmental Protection Agency, 1996). These standards and the number of samples that exceeded them are shown in table 3. Of the 15 constituents having standards or health advisories, 6 were exceeded by at least one sample, with one-half of these exceeded in only one sample. The three constituents that frequently exceeded a standard or health advisory are iron (62\%), manganese $(93 \%)$ and sodium (15\%). The iron and manganese standards are concerned with aesthetics and are not health related. Sodium above 20 $\mathrm{mg} / \mathrm{L}$ can have adverse health effects when consumed for a lifetime. People who should restrict sodium in their diet should be aware that substantial amounts of sodium can come from water withdrawn from buried aquifers.

Nitrate concentrations greater than $3.0 \mathrm{mg} / \mathrm{L}$ as nitrogen $(-\mathrm{N})$ in ground water indicate contamination from human sources (Madison and Brunett, 1985). Agricultural application of manure or chemical fertilizers, legume production, seepage from septic system and sewagetreatment plants, and subaerial (airfall and rainfall) deposition are human-related sources of nitrate. Nitrate in ground-water samples ranged from less than 0.05 to 77 $\mathrm{mg} / \mathrm{L}-\mathrm{N}$.

Five of 43 samples collected for this study (11\%) contained nitrate concentrations greater than the detection limit $(0.05 \mathrm{mg} / \mathrm{L}-\mathrm{N})$. The second highest nitrate concentration was $2.8 \mathrm{mg} / \mathrm{L}-\mathrm{N}$ indicating that the sample containing $77 \mathrm{mg} / \mathrm{L}-\mathrm{N}$ (well D30) (greater than 7 times the USEPA drinking water standard) was an extreme anomaly and may be contaminated. The Minnesota Department of Health (written commun., 1992) has 713 historical nitrate analyses of ground water from the study area. These historical samples have multiple detection limits because they were collected and analyzed over many years. Twentyfour analyses (3\%) had nitrate concentrations greater than the detection limit. Nitrate concentrations ranged from 0.1 to $1.5 \mathrm{mg} / \mathrm{L}-\mathrm{N}$. A detection limit of $0.1 \mathrm{mg} / \mathrm{L}-\mathrm{N}$ is probably lower than that for many of the historical data, accounting 
EXPLANATION

- Surficial aquifers Uppermost confined aquifers (observation wells) 11 (domestic wells) Granite aquifers

- Unknown aquifers 5

\section{4} 4<smiles>CC(C)O</smiles>

$M g$

$\mathrm{Ca}$
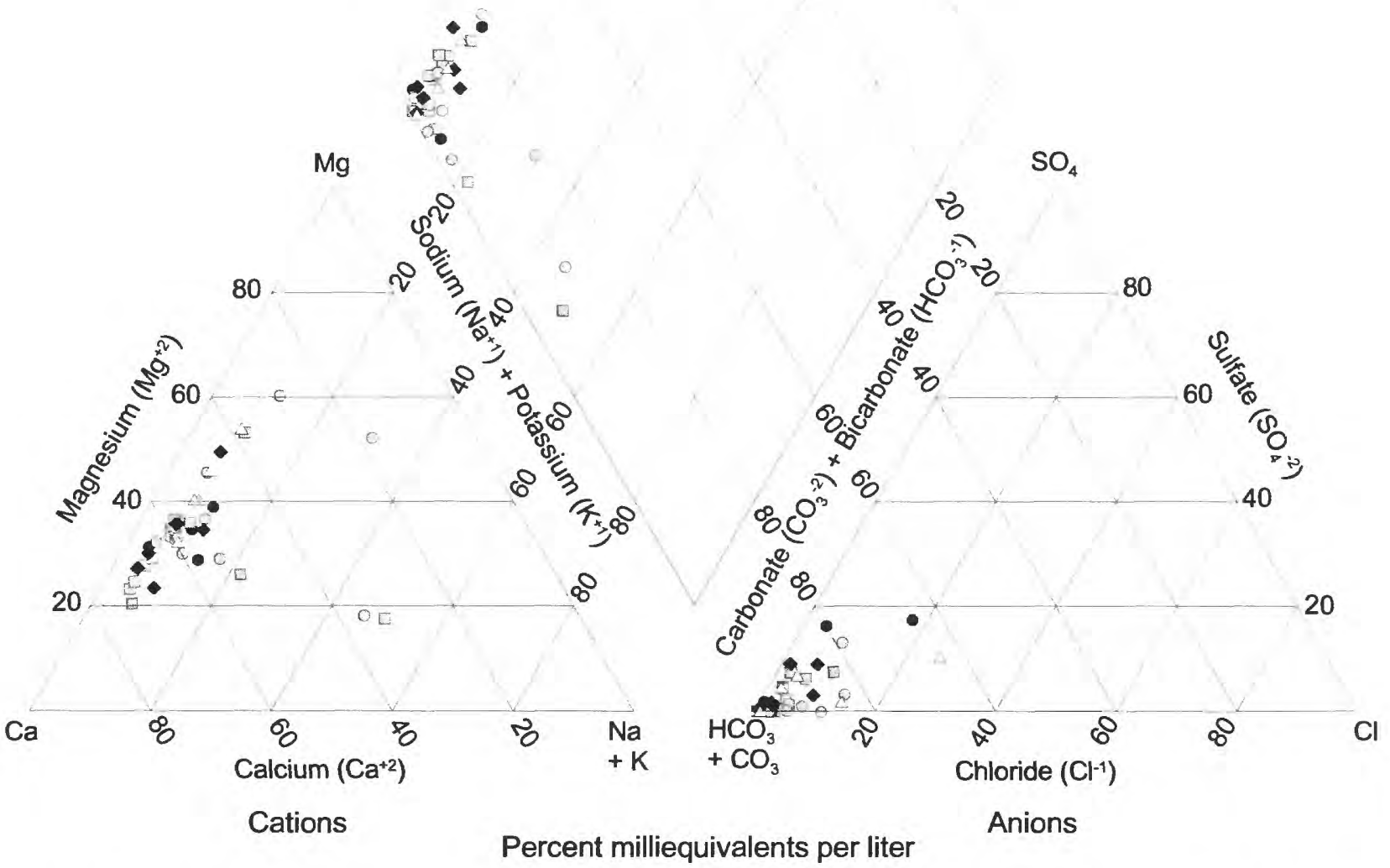

$\%$

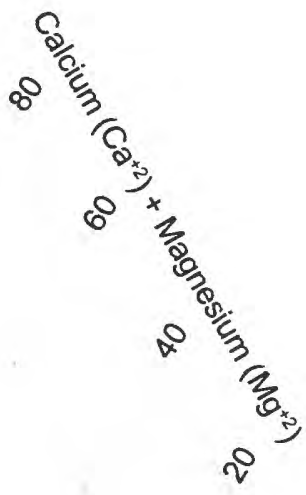

Figure 9. Major-ion composition of ground water in the Mille Lacs Lake study area, 1992-93

for the higher percentage of wells from this study with nitrate detected. Twenty historical nitrate concentrations in the

USGS data base (1965-1981) ranged from 0.02 to 9.6 $\mathrm{mg} / \mathrm{L}-\mathrm{N}$ with $55 \%$ of the samples greater than the unreported detection limits. The second highest nitrate concentration in this data base was $1.8 \mathrm{mg} / \mathrm{L}-\mathrm{N}$. With the exception of the high nitrate concentration at well D30 (77 $\mathrm{mg} / \mathrm{L}-\mathrm{N})$, the nitrate data collected for this study and historically indicate that all nitrate in water from aquifers may be from natural sources.
Samples from two domestic wells (wells D2 and D7) completed in buried aquifers were analyzed for nutrients (table 9), 5 trace metals, 57 USEPA priority pollutants (polycyclic aromatic hydrocarbons), 57 volatile organic compounds (VOCs), and 12 common pesticides and pesticide metabolites (table 4). Water from observation well O9 was analyzed for nutrients and 27 organochlorine pesticide and industrial compounds. Organochlorine compounds were not detected in this sample. Two trace metals were above the detection limits in wells D2, D7, and O9. Dissolved zinc concentrations in water from well D2 and D7 were $4 \mu \mathrm{g} / \mathrm{L}$ and $2,100 \mu \mathrm{g} / \mathrm{L}$, respectively. Dissolved 
Table 3 - Mille Lacs Lake ground-water samples exceeding United States Environmental

Protection Agency drinking water standards and health advisories.

$[\mathrm{mg} / \mathrm{L}$, milligrams per liter; $\mu \mathrm{g} / \mathrm{L}$, micrograms per liter;\%, percent; B, buried aquifers; $\mathrm{S}$, surficial aquifers; $\mathrm{G}$, bedrock aquifers;?, unknown aquifers; I, out of; SMCL, secondary maximum contaminant level ${ }^{1}$; MCL, maximum contaminant level ${ }^{2}$; HA, health advisory ${ }^{3}$ ]

\begin{tabular}{|c|c|c|c|}
\hline Constituent & Concentration & Standard or HA & Samples over standard ${ }^{4}$ \\
\hline Chloride & $250 \mathrm{mg} / \mathrm{L}$ & SMCL & $0 \%$ \\
\hline Fluoride & $2 / 4 \mathrm{mg} / \mathrm{L}$ & SMCL/MCL & $0 \%$ \\
\hline Iron & $300 \mu \mathrm{g} / \mathrm{L}$ & SMCL & $62 \%$, B: $20 / 27, S: 3 / 6$, G: $2 / 5, ?: 1 / 4$ \\
\hline Manganese & $50 \mu \mathrm{g} / \mathrm{L}$ & SMCL & $93 \%$, B: $25 / 27$, S: $5 / 6$, G: $4 / 5, ?: 2 / 4$ \\
\hline $\mathrm{pH}$ & $6.5-8.5$ & SMCL & $3 \%, \mathrm{~B}: 1 / 25, \mathrm{~S}: 0 / 6, \mathrm{G}: 0 / 5, ?: 0 / 4$ \\
\hline Sodium & $20 \mathrm{mg} / \mathrm{L}$ & HA & $15 \%$, B: $4 / 25, \mathrm{~S}: 0 / 6, \mathrm{G}: 1 / 5, ?: 1 / 4$ \\
\hline Sulfate & $250 / 500 \mathrm{mg} / \mathrm{L}$ & SMCL/MCL & $0 \%$ \\
\hline Dissolved solids & $500 \mathrm{mg} / \mathrm{L}$ & SMCL & $0 \%$ \\
\hline Ammonia & $30 \mathrm{mg} / \mathrm{L}$ & HA & $0 \%$ \\
\hline Nitrate plus nitrite & $10 \mathrm{mg} / \mathrm{L}$ as $\mathrm{N}$ & MCL & $2 \%, \mathrm{~B}: 1 / 28, \mathrm{~S}: 0 / 6, \mathrm{G}: 0 / 5, ?: 0 / 4$ \\
\hline Aluminum & $50-200 \mu \mathrm{g} / \mathrm{L}$ & SMCL & $0 \%$ \\
\hline Chromium & $100 \mu \mathrm{g} / \mathrm{L}$ & $\mathrm{MCL}$ & $0 \%$ \\
\hline Copper & $1000 / 1300 \mu \mathrm{g} / \mathrm{L}$ & SMCL/MCL & $0 \%$ \\
\hline Lead & $15 \mu \mathrm{g} / \mathrm{L}$ & MCL & $0 \%$ \\
\hline Zinc & $2000 \mu \mathrm{g} / \mathrm{L}$ & $\mathrm{HA}$ & 1 of 2 B samples $(2100 \mu \mathrm{g} / \mathrm{L})$ \\
\hline
\end{tabular}

copper concentration in water from well D7 was $36 \mu \mathrm{g} / \mathrm{L}$. Trace metals and organic chemicals were not present in samples from these wells probably because industrial compounds and pesticides are not widely used in this area, and because of the presence of the overlying confining unit. Zinc is used to galvanize steel and galvanized casings or well fittings may explain the high concentration in well D7. Detection of chloroform in well D2 $(3 \mu \mathrm{g} / \mathrm{L})$ may have originated from water used to clean sampling equipment.

\section{Ground-water susceptibility to contamination}

Two important factors affecting ground-water susceptibility to contamination are land-use activities and the thickness and permeability of confining units overlying an aquifer. Land cover in the study area is forest, agricultural lands, and wetlands. Commerce is concentrated around Mille Lacs Lake, dominated by the resort industry. Agriculture, light industry, transportation, sewagetreatment plants, and landfills are potential sources of contamination, but are not widespread. Therefore, contamination sources in the Mille Lacs Lake area tend to be few, small, and isolated. Areas most susceptible to contamination include the larger towns where sewagetreatment plants or stabilization ponds and light industry exist, and along well-traveled roads like U.S. Highway 169 , where transportation of petroleum and other chemicals occur. Wahkon, Isle, and Onamia each have a sewagetreatment plant (Minnesota Pollution Control Agency, 1987) (fig. 8). Improper disposal of wastes from industrial, commercial, and treatment facilities may introduce nutrients, organic chemicals, and trace metals to the ground water. Areas around landfills are also at risk for contamination. The landfill north of Opstead (fig. 8) has been closed within the last few years. Whereas, these areas present potential risks, proper operation and preventive care can offer long-term protection to the ground water. Once contamination reaches an aquifer, it can travel horizontally with the ground water and affect areas downgradient (fig. 8).

Surficial aquifers are most susceptible to contamination. Only sorption of contaminants to organic matter in soils and degradation by soil bacteria can prevent aquifer contamination by organic pollutants. The buried aquifers are protected by a layer of low-hydraulicconductivity material that slows the infiltration of contaminants dissolved by recharge water. Buried aquifer susceptibility decreases with increasing confining unit thickness and increases with increasing confining unit hydraulic conductivity. Aquifers overlain by thick confining units of low hydraulic conductivity are most protected from contamination. 
Table 4-Trace elements and organic compounds analyzed in ground water from

three wells in the Mille Lacs Lake study area.

( $\mu \mathrm{g} / \mathrm{L}$, micrograms per liter)

\begin{tabular}{|c|c|c|c|c|c|}
\hline Chemical name & $\begin{array}{c}\text { Detection } \\
\text { limit } \\
(\mu \mathrm{g} / \mathrm{L})\end{array}$ & Chemical name & $\begin{array}{c}\text { Detection } \\
\text { limit } \\
(\mu \mathrm{g} / \mathrm{L})\end{array}$ & Chemical name & $\begin{array}{c}\text { Detection } \\
\text { limit } \\
(\mu \mathrm{g} / \mathrm{L})\end{array}$ \\
\hline \multicolumn{6}{|c|}{ Trace Metals } \\
\hline aluminum & $<10$ & chromium & $<1$ & copper & $<1$ \\
\hline lead & $<1$ & zinc & $<1$ & & \\
\hline \multicolumn{6}{|c|}{ USEPA priority pollutants } \\
\hline phenol, 2-chloro & $<5.0$ & methane, bis (2-chloroethoxy) & $<5.0$ & para-chloro-meta cresol & $<30.0$ \\
\hline phenol, 2-nitro & $<5.0$ & ethane, hexachloro- & $<5.0$ & fluoranthene & $<5.0$ \\
\hline phenol, 4-nitro & $<30.0$ & ether, bis 2-chloroethyl & $<5.0$ & benzo $b$ fluoranthene & $<10.0$ \\
\hline phenol, 2,4-dichloro & $<5.0$ & ether, bis (2-chloroisopropyl) & $<5.0$ & benzo $\mathrm{k}$ fluoranthene & $<10.0$ \\
\hline phenol, 2,4-dimethyl & $<5.0$ & ether, 4-bromophenylphenyl & $<5.0$ & fluorene & $<5.0$ \\
\hline phenol, 2,4-dinitro & $<20.0$ & ether, 4-chlorophenylphenyl & $<5.0$ & acenaphthene & $<5.0$ \\
\hline phenol, 2,4,6-trichloro & $<20.0$ & benzene, nitro & $<5.0$ & acenapthylene & $<5.0$ \\
\hline phthalate, dimethyl & $<5.0$ & benzene, 1,3-dichloro- & $<5.0$ & pyrene & $<5.0$ \\
\hline phthalate, diethyl & $<5.0$ & benzene, 1,4-dichloro- & $<5.0$ & benzo a pyrene & $<10.0$ \\
\hline phthalate, dinoctyl & $<10.0$ & benzene, 1,2,4-trichloro- & $<5.0$ & indeno $(1,2,3-\mathrm{cd})$ pyrene & $<10.0$ \\
\hline phthalate, dinbutyl - & $<5.0$ & benzene, hexachloro & $<5.0$ & phenanthrene & $<5.0$ \\
\hline phthalate, bis (2-etylhexyl) & $<5.0$ & toluene, 2,4-dinitro & $<5.0$ & isophorone & $<5.0$ \\
\hline phthalate, $n$-butylbenzyl & $<5.0$ & toluene, 2,6-dinitro & $<5.0$ & hexachlorobutadiene & $<5.0$ \\
\hline n-nitrosodimethylamine & $<5.0$ & benzidine & $<40.0$ & 3,3'-dichlorobenzidine & $<20.0$ \\
\hline n-nitrosodiphenylamine & $<5.0$ & anthracene & $<5.0$ & 1,2-diphenylhydrazine & $<5.0$ \\
\hline n-nitrosodi-n-propylamine & $<5.0$ & 1,2,5,6-dibenzanthracene & $<10.0$ & hexachlorocyclopentadiene & $<5.0$ \\
\hline naphthalene & $<5.0$ & $\begin{array}{l}\text { benzo a anthracene, 1,2-benzan- } \\
\text { thracene }\end{array}$ & $<10.0$ & $\begin{array}{l}\text { benzo ghi perylene, } 1,1,2 \text {-ben- } \\
\text { zoperylene }\end{array}$ & $<10.0$ \\
\hline \multicolumn{6}{|c|}{ Organochlorine compounds } \\
\hline$\alpha$ benzene hexachloride & $<0.03$ & aldrin & $<0.04$ & endosulfan $\beta$ & $<0.04$ \\
\hline$\beta$ benzene hexachloride & $<0.03$ & dieldrin & $<0.02$ & toxaphene & $<2$ \\
\hline chlordane, trans- & $<0.10$ & $p, p^{\prime} \mathrm{DDE}$ & $<0.04$ & aroclor $1016 \mathrm{PCB}$ & $<0.1$ \\
\hline chlordane, cis- & $<0.10$ & endrin & $<0.060$ & aroclor $1242 \mathrm{PCB}$ & $<0.1$ \\
\hline lindane & $<0.03$ & endrin aldehyde & $<0.20$ & aroclor $1248 \mathrm{PCB}$ & $<0.1$ \\
\hline heptachlor & $<0.03$ & endosulfan I & $<0.10$ & aroclor $1254 \mathrm{PCB}$ & $<0.1$ \\
\hline heptachlor epoxide & $<0.80$ & endosulfan sulfate & $<0.60$ & & \\
\hline \multicolumn{6}{|c|}{ Pesticides and metabolites } \\
\hline atrazine & $<0.05$ & propazine & $<0.05$ & metolachlor & $<0.05$ \\
\hline atrazine, deethyl- & $<0.05$ & simazine & $<0.05$ & metribuzin, (sencor) & $<0.05$ \\
\hline atrazine, deisopropyl- & $<0.05$ & alachlor & $<0.05$ & prometon & $<0.05$ \\
\hline cyanazine & $<0.20$ & ametryn & $<0.05$ & prometryn & $<0.05$ \\
\hline \multicolumn{6}{|c|}{ Volatile organic compounds } \\
\hline benzene & $<0.2$ & methylchloride & $<0.2$ & propane, dibromochloro- & $<1.0$ \\
\hline benzene, chloro- & $<0.20$ & methylbromide & $<0.2$ & propene, 1,1-dichloro- & $<0.2$ \\
\hline benzene, bromo- & $<0.2$ & methylenechloride & $<0.2$ & propane,1,2-dichloro- & $<0.2$ \\
\hline benzene, 1,2,3-trichloro- & $<0.20$ & methane, dibromo- & $<0.2$ & propane,1,3-dichloro- & $<0.2$ \\
\hline benzene, isopropyl- & $<0.20$ & methane, chlorodibromo- & $<0.2$ & propane, 2,2-dichloro- & $<0.2$ \\
\hline benzene, $n$-propyl- & $<0.20$ & methane, dichlorobromo- & $<0.2$ & propane, 1,2,3-trichloro- & $<0.2$ \\
\hline benzene, $n$-butyl- & $<0.20$ & methane, dichlorodifluoro - & $<0.2$ & ethene, 1,1-dichloro- & $<0.2$ \\
\hline benzene, sec-butyl- & $<0.20$ & methane, trichlorofluoro- & $<0.2$ & ethene, cis-1,2-dichloro- & $<0.2$ \\
\hline benzene, tert-butyl- & $<0.20$ & chloroform & $<0.2$ & ethene, trans-1,2-dichloro- & $<0.2$ \\
\hline benzene, ethyl & $<0.2$ & bromoform & $<0.2$ & ethene, trichloro- & $<0.2$ \\
\hline xylene & $<0.20$ & carbontetrachloride & $<0.2$ & ethene, tetrachloro- & $<0.2$ \\
\hline toluene & $<0.2$ & ethane, chloro & $<0.2$ & propene, cis-1,3-dichloro- & $<0.2$ \\
\hline toluene, $o$-chloro- & $<0.2$ & ethane, 1,1-dichloro- & $<0.2$ & propene, trans-1,3-dichloro- & $<0.2$ \\
\hline toluene, $p$-chloro- & $<0.20$ & ethane,1,2-dibromo- & $<0.2$ & ether, 2-chloroethylvinyl- & $<1.0$ \\
\hline toluene, $p$-isopropyl- & $<0.20$ & ethane,1,2-dichloro- & $<0.2$ & ether, methyl tert-butyl- & $<1.0$ \\
\hline styrene & $<0.2$ & ethane, 1,1,1-trichloro- & $<0.2$ & vinylchloride & $<0.2$ \\
\hline pseudocumene & $<0.20$ & ethane,1,1,2-trichloro- & $<0.2$ & acrylonitrile & $<20$ \\
\hline
\end{tabular}


The thickness of the confining unit (fig. 4) ranges from 10 feet to 208 feet (west of Opstead). The confining unit provides protection to the aquifer because the vertical hydraulic conductivity is low $\left(9.92 \times 10^{-4} \mathrm{ft} / \mathrm{d}\right.$ to $1.67 \mathrm{x}$ $10^{-1} \mathrm{ft} / \mathrm{d}$ in cores tested, table 7) and slows the movement of contaminants. The Geologic Sensitivity Project Workgroup (1991) guidelines estimate that water will take about 20 years to infiltrate through a 10 -foot thick clay layer. Buried aquifers overlain by a confining unit from 10 to 50 feet thick, corresponding to areas with infiltration travel times from 20 to 100 years, are classified as low-susceptibility aquifers (Geologic Sensitivity Project Workgroup, 1991). Lateral movement of contaminants, poor well construction, or a hydraulic conductivity of the confining unit greater than normal, however, can still permit contamination of buried aquifers classified as low or very low susceptibility.

The tritium concentration of ground water can be used to test the contamination-susceptibility ratings discussed above. Tritium is a naturally occurring radioactive isotope of hydrogen produced at low but constant concentrations in the upper atmosphere by cosmic rays. When humans began to detonate nuclear weapons in the atmosphere, tritium concentrations increased many orders of magnitude. The maximum concentration occurred in 1963 when nuclear weapons testing moved underground and the tritium concentrations began to decrease through radioactive decay. Atmospheric water that eventually infiltrates to the ground water contains the atmospheric concentration of tritium. Ground water containing little or no tritium (less than 1 tritium unit) infiltrated before the start of atmospheric nuclear weapons tests in the early 1950's and are termed vintage waters (Walsh, 1992, p. 24-26). Water with substantial concentrations of tritium became ground water after the early 1950's and are termed recent waters. Ground water from aquifers beneath confining units 20 feet thick or more (infiltration times more than 50 years) would likely be vintage water, whereas, water in aquifers beneath thinner confining units may be recent water.

The Minnesota Department of Health collected and analyzed 7 ground-water samples on November 13, 1991, from wells located the southern shore of Mille Lacs Lake, for tritium and 12 inorganic chemicals. Six samples were from buried aquifers and one sample (Minnesota unique no. 227363) was from a bedrock aquifer. Walsh (1992, p. 61) reported that recent waters were dominant in this group, despite a low to very low conatmination-suseptibility rating of these aquifers. Within two miles of well yielding vintage water were wells yielding ground water of recent age (table 5). Recent water in aquifers underlying thick confining units may have originated from an aquifer where the confining unit was thin or absent. In areas where confining-unit Macropores, cracks and small lenses of coarse-grained sediments contained within confining units, may increase the potential for contamination.

\begin{tabular}{clccc}
\hline $\begin{array}{c}\text { Table 5-Confining unit thickness, well depth, and tritium concentration of ground } \\
\text { water from the south side of Mille Lacs Lake, 1991. } \\
\text { [mi, mile; data from Minnesota Department of Health] }\end{array}$ & $\begin{array}{c}\text { Confining unit } \\
\text { thickness } \\
\text { [feet] }\end{array}$ & $\begin{array}{c}\text { Well } \\
\text { depth } \\
\text { [feet] }\end{array}$ & $\begin{array}{c}\text { Tritium } \\
\text { concentration } \\
\text { [tritium units] }\end{array}$ \\
\hline $\begin{array}{c}\text { Minnesota unique } \\
\text { number }\end{array}$ & \multicolumn{1}{c}{ Location } & 85 & 90 & $<1$ \\
\hline 141388 & 1/2 mi N. of Vineland & 50 & 97 & 32 \\
229055 & 1 mi N. of Vineland & 125 & 168 & $<1$ \\
227363 & 1/2 mi W. of Isle & 33 & 113 & 18 \\
111761 & $1 / 2$ mi N. of Isle & 99 & 114 & 49 \\
214762 & Isle at highways 47 \& 27 & 60 & 101 & 31 \\
232345 & Onamia & - & 67 & 47 \\
238726 & South end of Ogechie Lake & & & \\
\hline
\end{tabular}

\section{Summary}

The Mille Lacs Lake study area is a $960-\mathrm{mi}^{2}$ area containing the ground-water and surface-water drainages of both Mille Lacs Lake and the first 12 miles of the Rum River. Within this area, available ground water occurs in saturated, overlapping, discontinuous, partially-connected, glacial aquifers and in bedrock aquifers. Data from project and private well logs suggest that glacial aquifers are small, local and isolated. No extensive glacial aquifer could be delineated. Surficial aquifers generally are less than $30 \mathrm{ft}$ thick, but can exceed $78 \mathrm{ft}$. The surficial aquifers north and south of Lake Onamia are in hydraulic connection with the lake, with an adjacent head $1.56 \mathrm{ft}$ higher than the lake in winter 1993. A confining unit composed mostly of till protects underlying buried aquifers from contamination by land uses. This confining unit is at least $10 \mathrm{ft}$ thick by definition but is at least $40 \mathrm{ft}$ thick at $61 \%$ of wells with geologic logs. Confining unit texture averaged $16 \%$ gravel, $43 \%$ sand, $32 \%$ silt, and $9 \%$ clay in samples from project test 
holes with hydraulic conductivities ranging from $9.92 \times 10^{-}$

${ }^{4}$ to $1.67 \times 10^{-1} \mathrm{ft} /$ day in tests on repacked core material.

Glacial aquifers buried beneath till form the uppermost confined (hereinafter, buried) aquifers and generally are from 3 to 15 feet thick, but may be as much as 118 feet thick. These buried aquifers occur beneath 10 to 60 feet of till and clay, but the till and clay may be as thick as 208 feet. Individual aquifers can be partially buried by till and therefore may contain surficial and buried areas. Most buried aquifers are isolated or only partially connected to other aquifers. Recharge water moves horizontally and vertically through other aquifers and through confining units to reach these buried aquifers. Discharge from buried aquifers is through well withdrawals, flow to surface-water bodies, and leakage to other aquifers. Buried aquifers may yield as much as 500 gallons per minute in some locations. In most areas, the specific capacity of these aquifers is less than 1 gallon per minute per foot but may be as much as 41.6 gallons per minute per foot.

Recharge to a buried aquifer northeast of Opstead was 6.86 in./yr during 1992-93. Ground water flows toward Mille Lacs Lake and the Rum River from a ground-water divide around the lake. This divide is low and possibly seasonally absent in three areas suggesting that Mille Lacs Lake water may recharge glacial aquifers in those areas. Small areas where the ground-water divide is not coincident with the surface-water divide suggests that inter-basin water transfer may occur in aquifers. Most ground water used is from buried aquifers. In 1992, 708 million gallons of water was withdrawn, of which the majority $(60 \%)$ was for domestic self supply. Ground water for public supply increased 53\% between 1985 and 1990 although total ground water withdrawals have remained constant since the 1960's.

Water samples from aquifers were of the calcium magnesium bicarbonate type. Hardness in the aquifers ranged from 66 to $750 \mathrm{mg} / \mathrm{L} \mathrm{CaCO}$ with a median values of $210 \mathrm{and} 180 \mathrm{mg} / \mathrm{L} \mathrm{CaCO}$ in buried and surficial aquifers respectively. Hardness in bedrock aquifers ranged from 240 to $260 \mathrm{mg} / \mathrm{L}$ with a median hardness of $310 \mathrm{mg} / \mathrm{L}$. Iron, manganese, and sodium frequently exceeded U.S.

Environmental Protection Agency drinking water standards or health advisories. The sodium health advisory level was exceeded in $15 \%$ of all samples collected. Nitrate in ground water appears to be from natural sources and was below U.S. Environmental Protection Agency drinking water standards with one exception. Five trace metals, U.S. Environmental Protection Agency priority pollutants (57 polycyclic aromatic hydrocarbons), 12 common pesticides and their metabolites, and 57 volatile organic compounds analyzed in two samples from buried aquifers were all below detection limits except for zinc, copper, and chloroform. These detections were all low concentrations except for one detection of zinc. These detections may be contamination from sampling equipment or cleaning fluids.

Sources of contamination, and confining unit thickness and permeability are important factors affecting groundwater susceptibility to contamination from land use. Contamination sources are greater near larger towns (or other settlements) and highways where industrial, commercial, agricultural, and sewage-treatment activities may be greater. Aquifers in areas with a thinner, more permeable confining unit are at higher risk of contamination. Although established guidelines suggest that areas with a confining-unit thickness of at least $10 \mathrm{ft}$ have low contamination susceptibility, tritium concentrations from water in buried aquifers around the south end of Mille Lacs Lake suggest that recharge water can reach these aquifers within a few decades.

\section{References cited}

Alexander, J.F., Jr., Zwick, P.D., Miller, J.J., and Hoover, M.H., 1984, Alafia River Basin land and water use projection model-Volume 1: Gainesville, University of Florida, $152 \mathrm{p}$.

Baker, D.G., Wallace W.N., and Kuehnast, E.L., 1979, Climate of Minnesota Part XII, The hydrologic cycle and soil and water: Minnesota Agricultural Experimentation Station Technical Bulletin 322, $23 \mathrm{p}$.

Breining, Greg, 1992, Secrets of the bogs: Minnesota Department of Natural Resources, The Minnesota Volunteer, p. 42-54.

Ericson, D.W., Lindholm, G.F., and Helgesen, J.O., 1974, Water resources of the Rum River watershed, east-central Minnesota: U.S. Geological Survey Hydrologic Investigations Atlas HA-509, 3 sheets, scale 1:250,000.

Fetter, C.W., 1988, Applied hydrogeology: Columbus, Ohio, Merrill Publishing Company, 592 p.

Folk, R.L., 1974, Petrology of sedimentary rocks: Austin, Texas, Hemphill, 182 p.

Freeze, R.A. and Cherry, J.A., 1979, Groundwater: Englewood Cliffs, New Jersey, Prentice-Hall, Inc., $604 \mathrm{p}$.

Geologic Sensitivity Project Workgroup, 1991, Criteria and guidelines for assessing geologic sensitivity of ground water resources in Minnesota: Minnesota Department of Natural Resources, $122 \mathrm{p}$. 
Hem, J. D., 1985, Study and interpretation of the chemical characteristics of natural waters: U.S. Geological Survey Water-Supply Paper 2254, $263 \mathrm{p}$.

Hobbs, H.C., and Goebel, J.E., 1982, Geologic map of Minnesota-Quaternary geology: Minnesota Geological Survey State Map Series S-1.

Kanivetsky, Roman, 1979, Regional approach to estimating the ground-water resources of Minnesota: Minnesota Geological Survey Report of Investigations 22, $13 \mathrm{p}$.

Leverett, Frank, 1932, Quaternary geology of Minnesota and parts of adjacent states: U.S. Geological Survey Professional Paper 161, 149 p.

Long, H.K., and Farrar, J.W., 1993, Report on the U.S. Geological Survey's evaluation program for standard reference samples distributed in October 1992 T-121 (trace constituents), M-124 (major constituents), N-36 (nutrients), N-37 (nutrients), P19 (low ionic strength) and $\mathrm{Hg}-15$ (mercury): U.S. Geological Survey Open-File Report 93-32, 114 p.

Madison, R.J., and Brunett, J.O., 1985, Overview of the occurrence of nitrate in ground water of the United States, in National Water Summary 1984: U.S. Geological Survey Water-Supply Paper 2275, p. 93-105.

Minnesota Pollution Control Agency, 1987, Wastewater disposal facilities inventory State of Minnesota: Minnesota Pollution Control Agency, $89 \mathrm{p}$.

Mooers, H.D., 1988, Quaternary history and ice dynamics of the late Wisconsin Rainy and Superior Lobes, central Minnesota: Ph.D. thesis, Department of Geology and Geophysics, University of Minnesota, Minneapolis, 200 p.

Myette, C.F., 1986, Hydrogeology of sand-plain aquifers in Carlton, Kanabec, and Pine Counties, east-central Minnesota: U.S. Geological Survey Water-Resources Investigations Report 85-4334, $66 \mathrm{p}$.

Omernik, J.M., and Gallant, A.L., 1988, Ecoregions of the Upper Midwest States: U.S. Environmental Protection Agency, EPA/600/3-88/037, 56 p.
Rasmussen, W.C. and Andreasen, G.G., 1959, Hydrologic budget of the Beaver Dam Creek Basin, Maryland: U.S. Geological Survey WaterSupply Paper 1472, 106 p.

Schneider, A.F., 1956, Pleistocene geology of central Minnesota: Geological Society of America Guidebook, part 3, p. 125-52.

Schwartz, G.M., and Thiel, G.A.,1963, 1963, Minnesota's rock and waters: Minneapolis, University of Minnesota Press, $366 \mathrm{p}$.

Southwick, D.L., Morey, G.B., and McSwiggen, P.L., 1988, Geologic map of the Penokean Orogen, central and eastern Minnesota, and accompanying text: Minnesota Geological Survey Report of Investigations $37,25 \mathrm{p}$.

Stark, J.R., Busch, J.P., and Deters, M.H., 1991, Hydrogeology and water quality of glacial-drift aquifers in the Bemidji-Bagley area, Beltrami, Clearwater, Cass, and Hubbard Counties, Minnesota: U.S. Geological Survey WaterResources Investigations Report 89-4136, 135 p.

Swain, F.M., 1992, Bottom sediments and organic geochemical residues of some Minnesota lakes: Minnesota Geological Survey Report of Investigations $41,65 \mathrm{p}$.

Thiel, G.A., 1947, The geology and underground waters of northeastern Minnesota: Minnesota Geological Survey Bulletin 32, $247 \mathrm{p}$.

Trotta, L.C., 1988, Aggregation of Minnesota water-use data and transfer of data to the National Water-Use Data System-

Procedures and programs: U.S. Geological Survey Open-File Report 87-40, 7 p., 2 appendices.

U.S. Environmental Protection Agency, 1996, Drinking water regulations and health advisories: U.S. Environmental Protection Agency, Office of Water, EPA 822-B-96-002, $11 \mathrm{p}$

Walsh, J.F., 1992, Tritium in groundwater as a tool to estimate well vulnerability: Minnesota Department of Health, $128 \mathrm{p}$. 
Winchell, N.H., 1888, Geology of Minnesota:

Minnesota Geological and Natural History Survey Final Report, v. 2, 695 p.

Woodward, D.G., 1985, Trends in municipal-well installations and aquifer utilization in southeastern Minnesota, 1880-1980: U.S. Geological Survey Water-Resources Investigations Report 83-4222, $99 \mathrm{p}$.

Wright, H.E., Jr., 1956, Sequence of glaciation in eastern Minnesota: Geological Society of America, Minneapolis Meeting Guidebook, Part 3, p. 1-24.

1964, The classification of the Wisconsin Glacial Stage: Journal of Geology, v. 72, p. 628-637.

-1972, Quaternary history of Minnesota, in Geology of Minnesota, a centennial volume: Minnesota Geological Survey, p. 515-547.

Wright, H.E., Jr., and Ruhe, 1965, Glaciation of Minnesota and lowa, in Wright, H.E., Jr. and Frey, D.G., eds., The Quaternary of the United States: Princeton, Princeton University Press, p.29-41.

Young, P.G., 1987, An analysis of water use in Minnesota agriculture: Minnesota Department of Natural Resources, St. Paul, 49 p. 
Supplemental information 


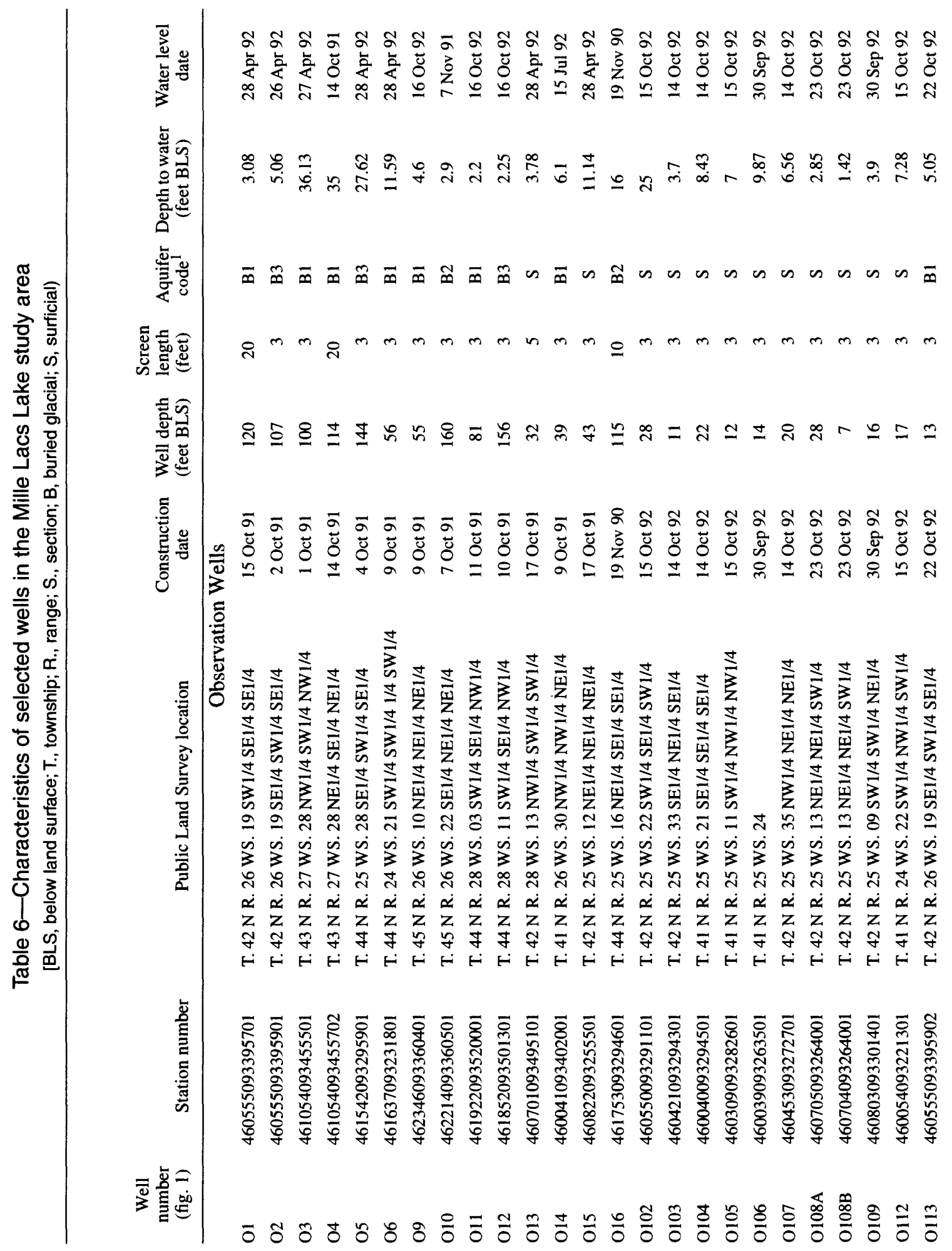




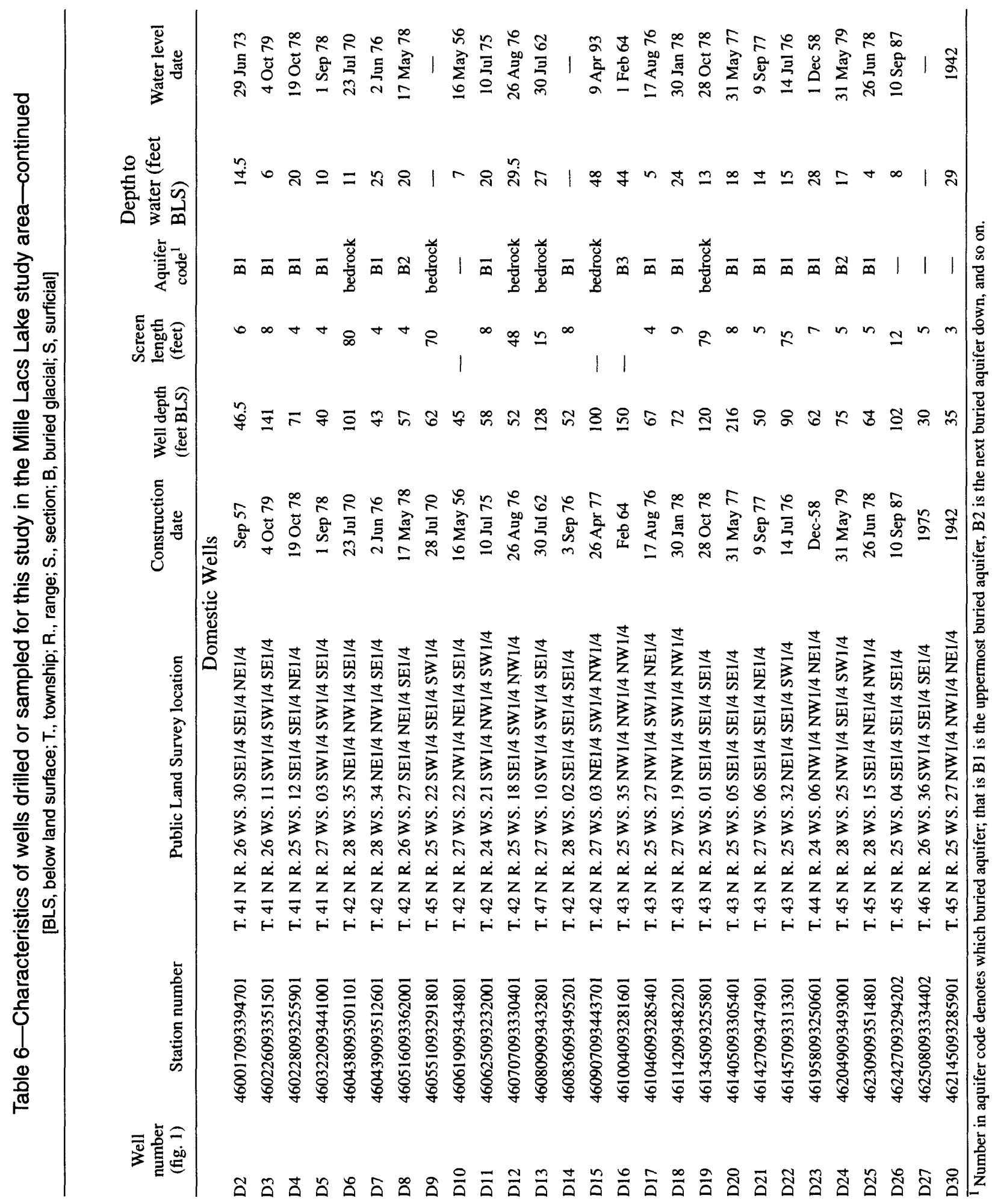




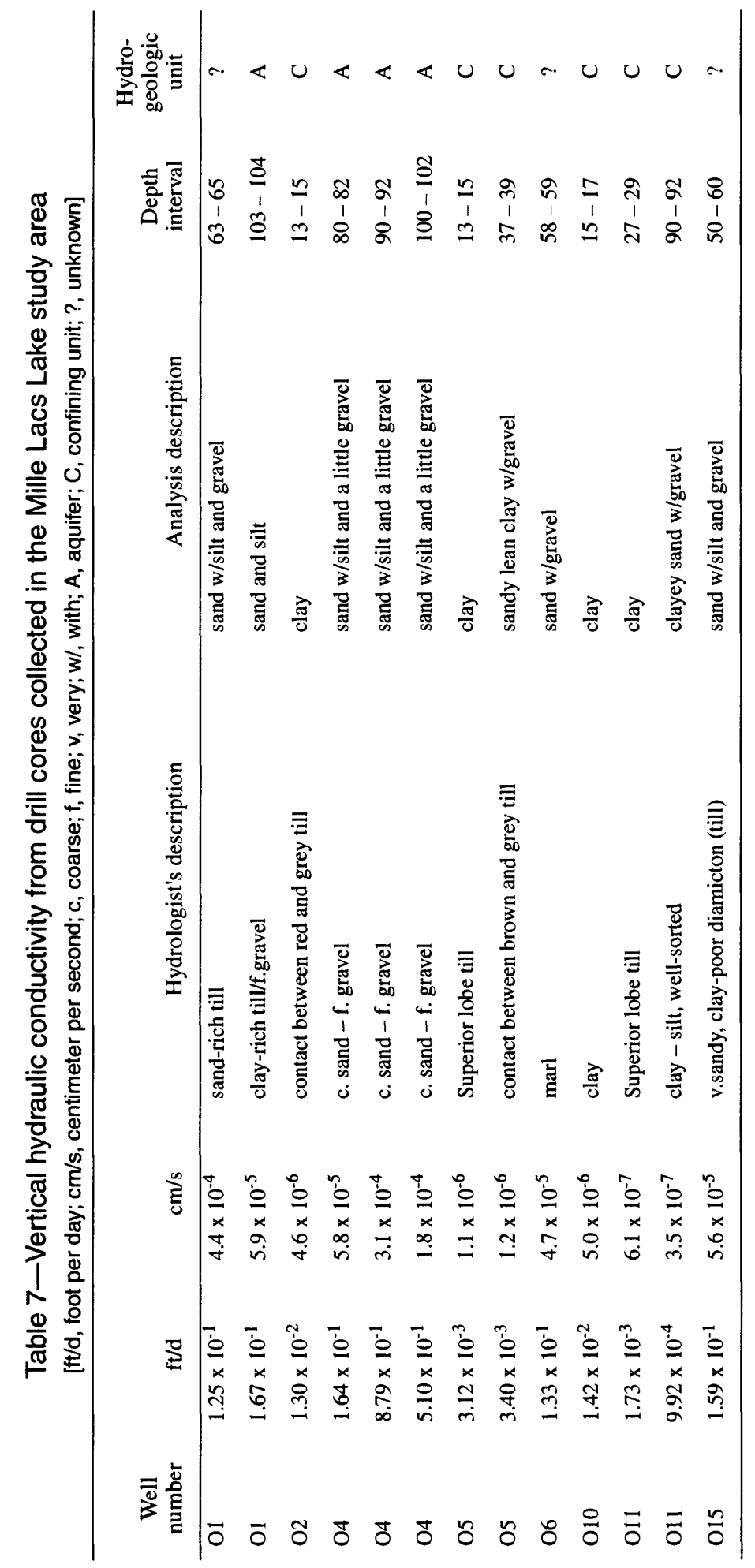




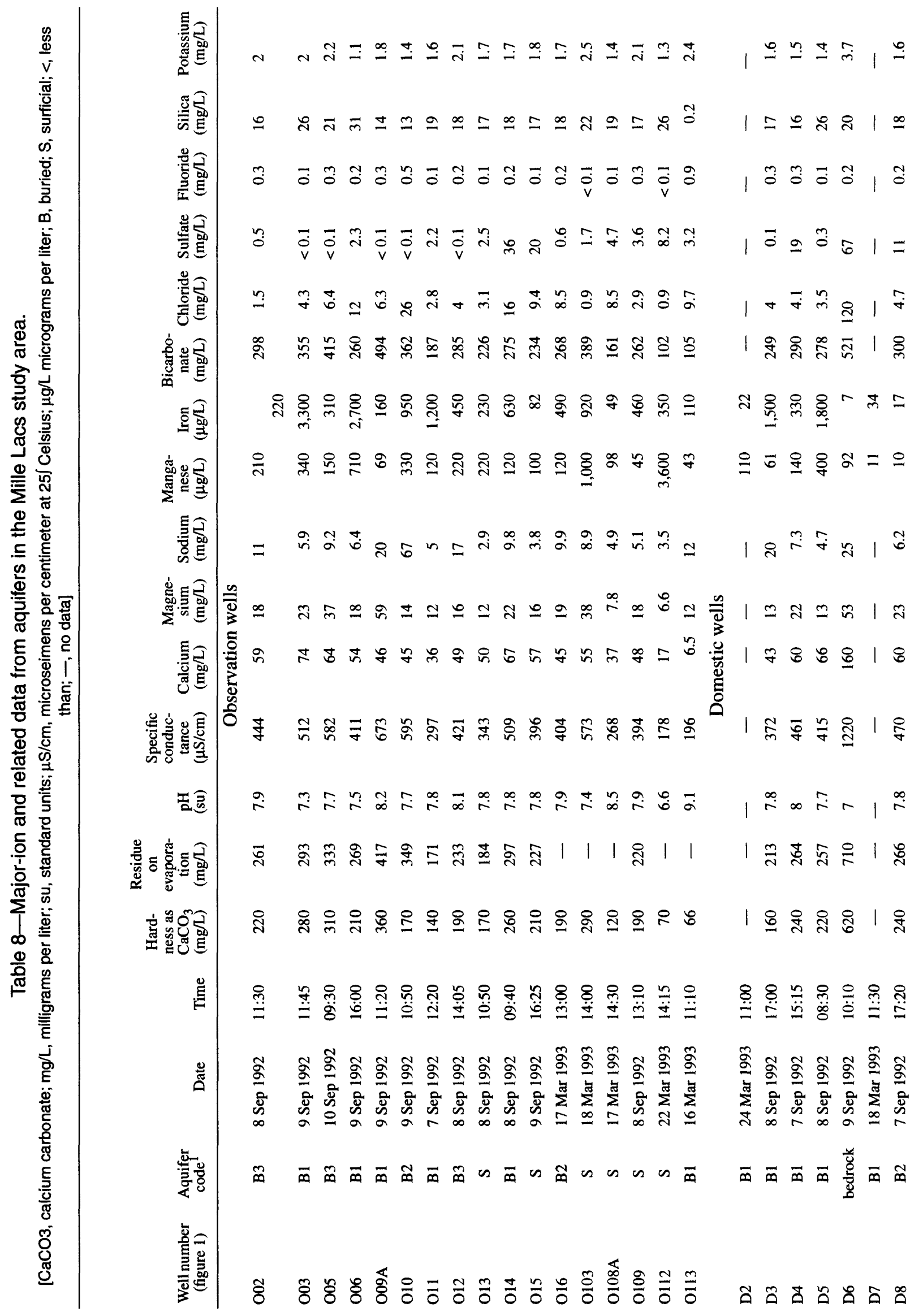




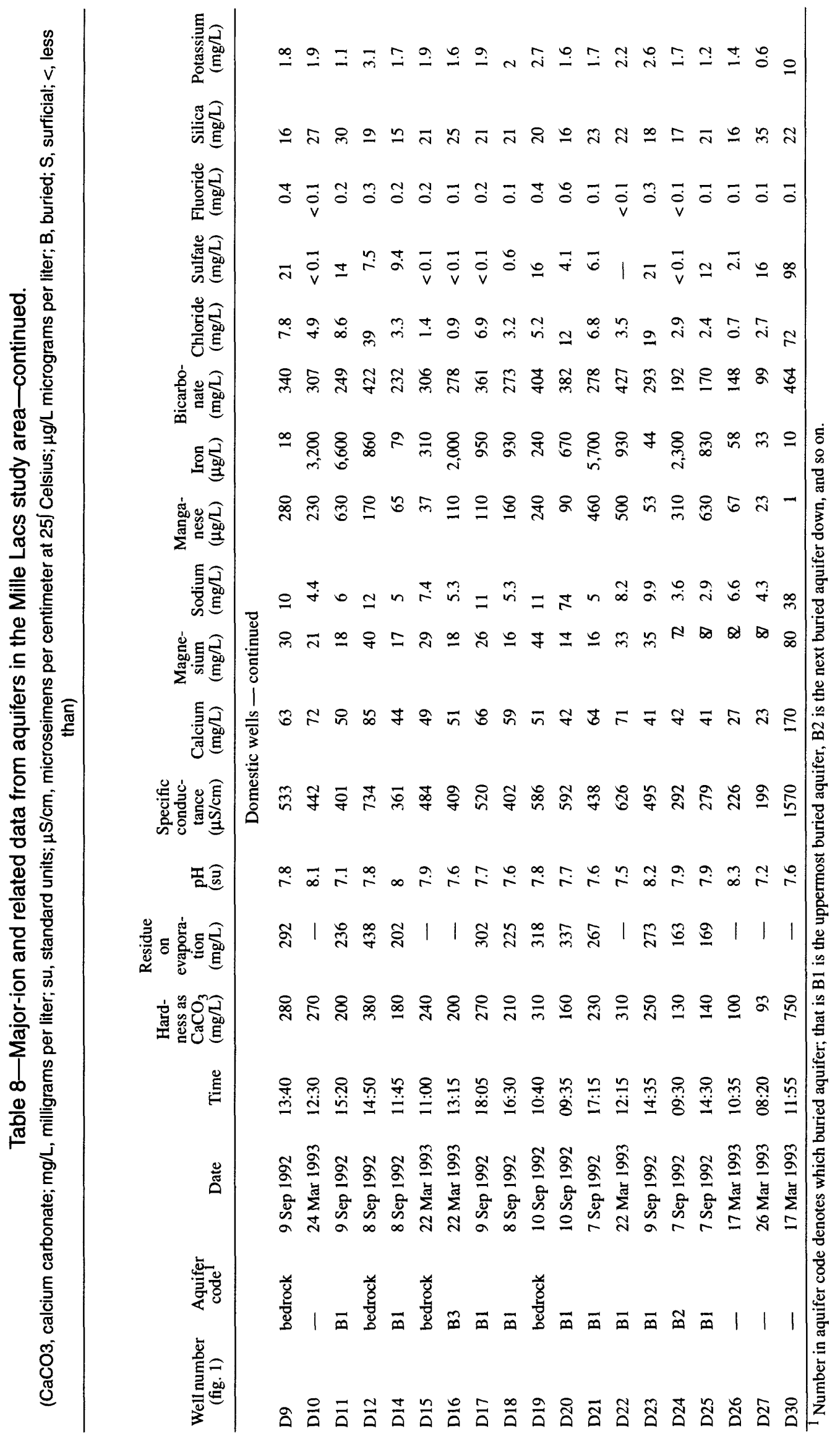


Table 9-Nutrient data from aquifers in the Mille Lacs study area.

( $N$, nitrogen; $\mathrm{P}$, phosphorus; $\mathrm{mg} / \mathrm{L}$, milligrams per liter; <, less than; B, buried; $\mathrm{S}$, surficial; -, no data)

\begin{tabular}{|c|c|c|c|c|c|c|c|c|}
\hline $\begin{array}{l}\text { Well } \\
\text { number } \\
\text { (fig. 1) }\end{array}$ & $\begin{array}{l}\text { Aquifer } \\
\text { code }^{1}\end{array}$ & Date & Time & $\begin{array}{l}\text { Nitrate plus } \\
\text { nitrite as } \mathrm{N} \\
(\mathrm{mg} / \mathrm{L})\end{array}$ & $\begin{array}{l}\text { Nitrite } \\
\text { as } N \\
(\mathrm{mg} / \mathrm{L})\end{array}$ & $\begin{array}{l}\text { Ammonia } \\
\text { as N } \\
(\mathrm{mg} / \mathrm{L})\end{array}$ & $\begin{array}{l}\text { Ammonia plus } \\
\text { organic } \\
\text { nitrogen as } N \\
(\mathrm{mg} / \mathrm{L})\end{array}$ & $\begin{array}{c}\text { Ortho- } \\
\text { phosphorus } \\
\text { as } \mathrm{P} \\
(\mathrm{mg} / \mathrm{L})\end{array}$ \\
\hline \multicolumn{9}{|c|}{ Observation wells } \\
\hline $\mathrm{O} 02$ & B3 & 8 Sep 1992 & $11: 30$ & $<0.05$ & $<0.01$ & 0.56 & 0.6 & 0.21 \\
\hline $\mathrm{O} 03$ & B1 & 9 Sep 1992 & $11: 45$ & $<0.05$ & $<0.01$ & 0.81 & 0.9 & 0.02 \\
\hline 005 & B3 & 10 Sep 1992 & $09: 30$ & $<0.05$ & $<0.01$ & 0.29 & 0.4 & 0.07 \\
\hline 006 & B1 & 9 Sep 1992 & $16: 00$ & $<0.05$ & $<0.01$ & 0.13 & 0.3 & 0.09 \\
\hline O09A & B1 & 9 Sep 1992 & $11: 20$ & $<0.05$ & $<0.01$ & 0.37 & 0.9 & 0.04 \\
\hline $\mathrm{O} 09 \mathrm{~A}$ & B1 & 26 Mar 1993 & $10: 30$ & $<0.05$ & 0.01 & 0.32 & 0.9 & 0.03 \\
\hline $\mathrm{O} 10$ & B2 & 9 Sep 1992 & $10: 50$ & $<0.05$ & $<0.01$ & 1.5 & 1.6 & 0.37 \\
\hline 011 & B1 & 7 Sep 1992 & $12: 20$ & $<0.05$ & $<0.01$ & 0.76 & 0.9 & 0.11 \\
\hline $\mathrm{O} 12$ & B3 & 8 Sep 1992 & $14: 05$ & $<0.05$ & $<0.01$ & 0.46 & 0.6 & 0.15 \\
\hline 013 & $S$ & 8 Sep 1992 & $10: 50$ & $<0.05$ & $<0.01$ & 0.02 & $<0.2$ & 0.05 \\
\hline $\mathrm{O} 14$ & B1 & 8 Sep 1992 & $09: 40$ & $<0.05$ & $<0.01$ & 0.13 & 0.3 & 0.07 \\
\hline 015 & $\mathrm{~S}$ & 9 Sep 1992 & $16: 25$ & $<0.05$ & $<0.01$ & 0.02 & $<0.2$ & 0.02 \\
\hline O16 & B2 & 17 Mar 1993 & $13: 00$ & $<0.05$ & $<0.01$ & 0.31 & 0.4 & 0.06 \\
\hline $\mathrm{O} 103$ & $\mathrm{~S}$ & 18 Mar 1993 & $14: 00$ & $<0.05$ & 0.02 & 0.04 & 0.8 & 0.13 \\
\hline O108A & $\mathrm{S}$ & 17 Mar 1993 & $14: 30$ & $<0.05$ & 0.02 & 0.08 & 0.2 & 0.1 \\
\hline 0109 & $\mathrm{~S}$ & 8 Sep 1992 & $13: 10$ & $<0.05$ & $<0.01$ & 0.13 & $<0.2$ & 0.05 \\
\hline $\mathrm{O} 112$ & $\mathrm{~S}$ & 22 Mar 1993 & $14: 15$ & $<0.05$ & 0.01 & 0.13 & 0.7 & $<0.01$ \\
\hline $\mathrm{O} 113$ & $\mathrm{~B} 1$ & $16 \operatorname{Mar} 1993$ & $11: 10$ & $<0.05$ & 0.02 & 0.23 & 0.4 & $<0.01$ \\
\hline \multicolumn{9}{|c|}{ Domestic wells } \\
\hline D2 & B1 & 24 Mar 1993 & $11: 00$ & $<0.05$ & 0.02 & 0.02 & 0.3 & $<0.01$ \\
\hline D3 & B1 & 8 Sep 1992 & $17: 00$ & $<0.05$ & $<0.01$ & 0.44 & 0.5 & 0.11 \\
\hline D4 & B1 & 7 Sep 1992 & $15: 15$ & $<0.05$ & $<0.01$ & 0.06 & $<0.2$ & 0.05 \\
\hline D5 & B1 & 8 Sep 1992 & $08: 30$ & $<0.05$ & $<0.01$ & 0.18 & 0.4 & 0.12 \\
\hline D6 & bedrock & 9 Sep 1992 & $10: 10$ & 2.8 & $<0.01$ & 0.02 & 0.5 & 0.02 \\
\hline D7 & B1 & $18 \operatorname{Mar} 1993$ & $11: 30$ & 0.89 & $<0.01$ & 0.02 & $<0.2$ & 0.01 \\
\hline D8 & B2 & 7 Sep 1992 & $17: 20$ & 0.94 & $<0.01$ & $<0.01$ & $<0.2$ & 0.02 \\
\hline D9 & bedrock & 9 Sep 1992 & $13: 40$ & $<0.05$ & $<0.01$ & 0.1 & 0.2 & 0.06 \\
\hline D10 & - & $24 \operatorname{Mar} 1993$ & $12: 30$ & $<0.05$ & 0.01 & 0.54 & 0.6 & $<0.01$ \\
\hline D11 & B1 & 9 Sep 1992 & $15: 20$ & $<0.05$ & $<0.01$ & 0.09 & 0.2 & 0.03 \\
\hline D12 & bedrock & 8 Sep 1992 & $14: 50$ & $<0.05$ & $<0.01$ & 0.3 & 0.3 & 0.06 \\
\hline D14 & B1 & 8 Sep 1992 & $11: 45$ & $<0.05$ & $<0.01$ & 0.02 & $<0.2$ & 0.01 \\
\hline D15 & bedrock & 22 Mar 1993 & $11: 00$ & $<0.05$ & $<0.01$ & 0.26 & 0.7 & $<0.01$ \\
\hline D16 & B3 & 22 Mar 1993 & $13: 15$ & $<0.05$ & $<0.01$ & 0.19 & 0.3 & 0.06 \\
\hline D17 & B1 & 9 Sep 1992 & $18: 05$ & $<0.05$ & $<0.01$ & 0.56 & 0.7 & 0.09 \\
\hline D18 & B1 & 8 Sep 1992 & $16: 30$ & $<0.05$ & $<0.01$ & 0.19 & $<0.2$ & 0.02 \\
\hline D19 & bedrock & 10 Sep 1992 & $10: 40$ & $<0.05$ & $<0.01$ & 0.08 & $<0.2$ & 0.02 \\
\hline D20 & B1 & 10 Sep 1992 & $09: 35$ & $<0.05$ & $<0.01$ & 1.4 & 1.5 & 0.29 \\
\hline $\mathrm{D} 21$ & $\mathrm{~B} 1$ & 7 Sep 1992 & $17: 15$ & $<0.05$ & $<0.01$ & 0.49 & 0.6 & $<0.01$ \\
\hline D22 & B1 & 22 Mar 1993 & $12: 15$ & $<0.05$ & 0.01 & 0.3 & 0.6 & $<0.01$ \\
\hline $\mathrm{D} 23$ & B1 & 9 Sep 1992 & $14: 35$ & $<0.05$ & $<0.01$ & 0.08 & $<0.2$ & 0.02 \\
\hline $\mathrm{D} 24$ & B2 & 7 Sep 1992 & $09: 30$ & $<0.05$ & $<0.01$ & 1.1 & 1.2 & 0.1 \\
\hline D25 & B1 & 7 Sep 1992 & $14: 30$ & $<0.05$ & $<0.01$ & 0.07 & $<0.2$ & 0.03 \\
\hline D26 & - & 17 Mar 1993 & $10: 35$ & $<0.05$ & $<0.01$ & 0.15 & $<0.2$ & 0.06 \\
\hline D27 & - & 26 Mar 1993 & 08:20 & 0.19 & 0.01 & 0.03 & $<0.2$ & 0.02 \\
\hline D30 & - & 17 Mar 1993 & $11: 55$ & 77 & 0.02 & 0.02 & 0.7 & 0.02 \\
\hline
\end{tabular}




\section{Water-use data}

This section contains the details of ground-water use estimates. These data came from a field survey along county and State highways. Many estimates of the rate of use for a particular activity are based on a study of water use by landuse type conducted by Alexander and others (1984). Such rate information, in combination with the knowledge of the general extent of the buried aquifers (fig. 5), and a survey of water users conducted for this study, allow estimates of pumpage from these aquifers to be calculated, given that they are the primary source of ground water. Water-use categories and withdrawal estimates are explained for the entire study area. Measurements of withdrawals by larger users are provided by the Minnesota Department of Natural Resources (MDNR).

\section{Public supply}

Ground water is used for public supply at five municipalities and at several mobile home parks, state parks, and wayside rests. Estimated withdrawals from parks and wayside rests is 542,000 gallons for 1992 . Ground water is also used for public supply at mobile home parks and town-home associations in Mille Lacs County, was about 3.30 million gallons. Combined withdrawals from the five municipal supplies were about 158 million gallons, based on 1991 reported pumpage (Minnesota Department of Natural Resources, written commun., 1992). Total publicsupply withdrawals amounted to about 162 million gallons in 1992.

\section{Commercial self supply}

There are many privately supplied commercial establishments, although the volume of individual usage is small. Within the study area 222 commercial wells. There are several commercial operations using water at one resort or site. For example, a resort may rent cabins and campsites, have a bar and a restaurant, and sell bait. A survey done for this study identified 2,406 separate commercial operations at the 222 sites. The total withdrawals for privately supplied commercial wells was estimated to be 85 million gallons. This represents 12 percent of total ground-water use, which is more than irrigation and industrial use combined.

\section{Irrigation and industrial self supply}

Irrigation use of ground water includes 2 corn-crop irrigators, one west and one south of Mille Lacs Lake, and a variety of small non-crop irrigators. The non-crop irrigators include golf courses, greenhouses, and cemeteries. Nursery and horticultural irrigation occur north of Onamia and Malmo, and near Wahkon, and east of Isle. Irrigation withdrawals amounted to about 9 million gallons in 1992.
The study area has 23 privately supplied industrial-use sites. These industries use water for food processing, metal fabrication, and wood products. Large industrial users of ground water are few. Total privately supplied industrial withdrawals amounted to about 28 million gallons in 1992.

\section{Domestic self supply}

Domestic use of ground water is based on the year round population of the study area $(17,576)$-minus the population served by public supplies $(4,392$ based on 1990 census). The rate of domestic use of ground water is estimated to be 88 gallons per person per day (Trotta, 1988, p. B-44). Total privately supplied domestic withdrawals amounted to 424 million gallons in 1992. More ground water was withdrawn for privately supplied domestic use than for any other category. 